\title{
Leveraging Spirituality and Religion in European For-profit-organizations: a Systematic Review
}

\author{
Lydia Maidl $^{1}$ (D) $\cdot$ Ann-Kathrin Seemann ${ }^{2} \cdot$ Eckhard Frick $^{3}$ (D) $\cdot$ Harald Gündel $^{4}$. \\ Piret Paal ${ }^{5}$
}

Received: 25 February 2021 / Accepted: 9 November 2021 / Published online: 26 January 2022

(c) The Author(s) 2021

\begin{abstract}
This systematic review synthesises the available evidence regarding the European understanding of workplace spirituality (definitions), the importance of spirituality and religion (evidence) as well as spiritual leadership (meaning and practice) in for-profitorganizations. The search for eligible studies was conducted in OPAC Plus, SCOPUS, Science Direct, JSTOR, EBSCO, and Google Scholar from 2007/01 to 2017/07. Three independent scholars extracted the data. Twenty studies were included (two mixed-methods, eight quantitative, ten qualitative) for the final quality assessment. A study quality assessment and thematic analysis was conducted. This review gives suggestions for study quality improvement and reporting. Thematically, two different approaches to religion and spirituality (R/S) were detected: a) work has a spiritual dimension and b) religious and spiritual orientation as "spiritual capital". Studies demonstrated positive effect on job satisfaction, health, commitment, company productivity and sustainability; Christian leadership does not address personal religious orientation; the spiritual dimension may lead to a change of perspective; workplace spirituality may exploit people for profit-oriented business goals; non-white Muslims experience discrimination. This systematic review provides robust evidence and findings for evidence-informed policymaking and encourages a more rigorous research in this field of study.
\end{abstract}

Keywords Spiritual leadership · Workplace spirituality · Quality of work life · Sustainability $\cdot$ Human resource management $\cdot$ European for-profit organizations

Lydia Maidl

Lydia.Maidl@1mu.de

1 Ludwig-Maximilians-Universität, Geschwister-Scholl-Platz 1, 80539 Munich, Germany

2 Institute of Tourism, Lucerne University of Applied Sciences of Arts, Rösslimatte 48, 6002 Lucerne, Switzerland

3 Professorship of Spiritual Care \& Psychosomatic Health, University Hospital rechts der Isar, Technical University of Munich, Kaulbachstr. 22a, 80539 Munich, Germany

4 University Hospital Ulm, Albert-Einstein-Allee 23, 89081 Ulm, Germany

5 Institute of Nursing Science and Practice, Paracelsus Medical University Salzburg, Strubergasse 21, 5020 Salzburg, Austria 


\section{Introduction}

Studying workplace spirituality is an open field of research that examines spiritual and religious orientation(s) at different levels, such as individual, organizational and societal, and analyses its consequences for educational, managerial and marketing purposes. The evidence demonstrates that to succeed and improve, all profit-oriented organizations must constantly be on the lookout for values and norms that support sustainable human resource management, advance the image of the organization (branding) and help to produce products that are in compliance with societal norms and consumer values. Thus, there is growing pressure to not only produce accordingly, but also to represent and live these values within the organization. Therefore, current leadership and Human Resource Management (HRM) research is constantly searching for solutions supporting the growth of emotional, spiritual, cultural, intentional and appreciative intelligence in leaders and decision-makers (Martin and Hafer 2009; Šilingienè and Škérienė 2015; Parkkali et al. 2015; Rosenauer et al. 2016; Kaufmann and Gaeckler 2015; Kaufmann and Wagner 2017). The ability to manage the 'spiritual capital' in the workplace has been called "the missing link in the process of human development that should be identified and considered as an important factor for developed and morally qualified human resources" (Ahmed et al. 2016, p. 165). Accordingly, the ongoing discussions call for a turn in management styles, in particular, when facing the challenge of HRM in the workplace.

\section{Cultural Diversity and Human Resource Management}

Modern HRM is a wicked problem, because trying to change a single agent calls for large system initiatives (Waddock et al. 2015). Current HRM faces numerous challenges, such as motivating and keeping elderly employees (Kurek and Rachwał 2011, Sturz and Zografos 2014, Vasconcelos 2015; 2018), while making organizations attractive for Generations Y and Z (Sullivan et al. 2009, Brown et al. 2012, Baumane-Vītoliṇa et al. 2017, Chawla et al. 2017), supporting female (Bark et al. 2014) and LGBTIQ+ journeys (Köllen 2016, Pichler et al. 2017), maintaining an appropriate work environment for people with disabilities (Hogan et al. 2012, Kulkarni and Rodrigues 2014) and addressing employees' struggles with various lifestyle and health issues, such as diabetes (Stynen et al. 2015), obesity (Levay 2014), alcohol and substance abuse (Belhassen and Shani 2012) or helping those suffering from violence at home or at the workplace (Alsaker et al. 2016).

In addition to these aspects, there is the paramount problem of how to adapt to the manifold cultural identities in the workplace. This challenge spans from international talent management (Gallardo-Gallardo et al. 2020) to expatriate issues (Lazarova et al. 2010), as well as leveraging multi-ethnic, national and religious identities (Byrne et al. 2011, Tracey 2012, Ghumman et al. 2013, Khattab and Johnston 2015). To overcome these and other HRM challenges, adopting a model of workplace spirituality might seem a useful forthcoming initiative.

\section{Workplace Spirituality - Fostering Oneness and Belonging}

Many of the empirical studies have demonstrated a positive effect of spirituality on job commitment, satisfaction and performance. The conventional strategy of organizations lies in helping their employees flourish by enhancing the individual's knowledge, skills, abilities and emotion control (Ahmed et al. 2016). Accordingly, spiritual values in employees 
have been positively associated with their mental well-being and low occupational stress, whereas the spiritual practices are positively associated with low work-related exhaustion and burnout (Arnetz et al. 2013; Nowrouzi et al. 2015). Other studies are demonstrating positive results in employees' altruism and conscientiousness, self-career management, reduced inter-role conflict, reduced frustration, organization based self-esteem, involvement, retention and ethical behaviour (Geigle 2012). Based on earlier findings, it can be concluded that spirituality benefits employees and supports organizational performance by enhancing employee well-being and quality of life, providing a sense of purpose, meaning, interconnectedness and community (Karakas 2010). The problem is that these studies have applied measures that enable understanding spirituality, spiritual needs and personal growth in individual employees or managers, however, the challenges and changes at group and organizational level have been largely neglected (Alcázar et al. 2013; Kulik 2014; Sullivan and Baruch 2009). Thus, there is a solemn need to explore and measure the effectiveness of diversity management activities in order to understand why, when and where adopting a workplace spirituality model might be forthcoming.

An additional problem is that there is no consensus on what workplace spirituality actually means. It has been suggested that in spiritually driven workplaces, people follow the model of minimization - meaning that they tend to highlight their similarities and ignore their differences (Ameli and Molaei 2012). Workplace spirituality has been linked to the 'oneness principle' indicating that "when you see no other, you help and support the correspondent no matter what his or her position/race/religion.” (Çelik 2012, p. 71). Accordingly, it is to be understood as a construct delivering a sense of connectedness or belonging linked to workplace specific moral boundaries and values.

\section{Workplace Spirituality and Religion}

When examining workplace spirituality and spiritual leadership, most researchers combine spirituality and religion (Dent et al. 2005), which is problematic for several reasons. Workplace spirituality is aiming at minimizing differences by creating an organizational system of meaning and delivering the message of community. Accordingly, "many organizations appear increasingly willing to play the role of secular religion, where the founders may become deities of sorts; key insiders may become clergy; jobs, callings; institutionalized processes, rituals; and failings, sins." (Ashforth and Vaidyanath 2002, p. 359). Creating an Olympus, a workplace full of gods and good will, no matter how innovative and inspiring, has its downsides calling for caution, in particular, when it comes to respecting employees as individuals each with their cultural and religious attachments.

Ignoring the issue of formal religion over workplace spirituality may have serious consequences for individuals, organizations and for societies (Alidadi and Foblets 2012). The consequences have not been examined and understood yet, however, Karakas has identified common problems connected to (mis)managing workplace spirituality. First and foremost is the danger of proselytism (the attempt to convert people to another religion or opinion), followed by the issue of compatibility, the risk of spirituality becoming a fad or a management tool to manipulate employees, the legitimacy problem the field of spirituality at work faces in theory, research and practice, the accommodation of spiritual requests, respect for diversity, openness and freedom of expression as well as acknowledgement of employees as individuals (Karakas 2010). This extensive list of problems clearly calls for an intelligent approach not only regarding management styles, but also in research. 
It appears that the contradiction between implementing workplace spirituality models at work and (dis)respecting worker's religion has led to a point, where many people simply wish that religion had no foothold in the workplace (Borstorff and Arlington 2011). This is all the more reason to take employees' religious and faith-related needs seriously, when studying workplace spirituality and spiritual leadership.

\section{Aims and Objectives}

For the past decade, the meaning of spirituality and religion in the workplace and in HRM has been the topic of many academic research endeavours. The importance of this topic for research becomes apparent considering the number of published books (Antwi 2017; Charles 2016; Farina 2015; Fry and Altman 2013; Lalani 2014; Marshall 2012; Morton 2015; Mugalu 2010; Ngambi 2011; Peltonen 2017; Scalise 2007) or scientific reviews conducted to investigate, explore, and discuss the various aspects of workplace spirituality and the management of religion and/or spirituality $(\mathrm{R} / \mathrm{S})$ at the individual, organizational or societal level. Previously conducted reviews (Lizardo 2011; Ratnakar and Nair 2012; Tracey 2014; Tracey 2012; Ghumman et al. 2013; Miller and Ewest 2013; Balog et al. 2014; Habib Rana and Shaukat Malik 2016) have proposed arguments, conclusions and recommendations, which are contradictory and inconclusive. Therefore, the principal questions regarding what is workplace spirituality, why workplace spirituality matters, how to manage workplace spirituality and what to do about religion at the organizational level, still remain relevant. As the majority of evidence regarding managing R/S at organizations stems from non-European countries (Hashim et al. 2015), the following review pays special attention to knowledge and evidence emerging from the European context.

\section{Methods}

This is a systematic review of literature to provide a complete and comprehensive summary of evidence on how to leverage spirituality and religion in for-profit-organizations in the European context. The findings of this review are presented according to the PRISMA (Moher et al. 2010) guideline. The study protocol was published on ResearchGate on February 2, 2018 (Paal 2018).

\section{Eligibility}

This review considered quantitative, qualitative and mixed method studies. Quantitative designs include experimental studies (including randomized controlled trials, non-randomized controlled trials, other quasi-experimental studies including before and after studies) and observational designs (descriptive studies, cohort studies, cross sectional studies, case studies and case series studies). Qualitative designs include any studies that focus on qualitative data, such as, but not limited to, case studies, grounded theory, ethnography designs or discursive analysis.

This review concentrated on studies published between January 2007 and July 2017. Only publications in the English language are included. Books, book chapters, book reviews, conference proceedings, editorials and theses are excluded from this review. 
For inclusion/exclusion decision making, we applied the following PICO framework (Schardt et al. 2007):

- Population: Adult workers and managers of any for-profit-organization in European countries.

- Intervention: Any introduction/application/assessment of $\mathrm{R} / \mathrm{S}$ in the workplace at group or organizational level.

- Comparison: Any methods applied, including comparison between European and nonEuropean countries.

- Outcomes: Any reported outcomes on $\mathrm{R} / \mathrm{S}$ in the workplace at group or organizational level, or in management.

\section{Exclusion Criteria}

We excluded adolescents, retired, unemployed workers, stakeholders, ethnic minorities or expats at non-profit and governmental organizations, private or public military, prison, church, school, higher education unit, health institution, virtual teams and digital society or workforce outside the workplace in non-European countries. Also excluded were studies tackling knowledge transfer, communication, organizational or life-long-learning, analysing and exploring organizational change, workplace issues and leadership challenges without an explicit connection to spirituality and religion.

\section{The Search Strategy}

The search strategy was deliberately kept broad in order to map the range of topics hypothetically connected to the workplace R/S, R/S in HRM and spiritual leadership. The MeSh browser (Mesh on Demand n.d.) was visited to extend the search words. Regular meetings were held to discuss the primary findings in order to fine-tune the search strategy and key words. Word combinations and search terms were used as demonstrated in the following figure (Fig. 1).

The search was conducted by two independent scholars in following electronic databases and generic search engines: (1) OPAC Plus (2007/01-2017/07) (2) SCOPUS

manage(ing) / leverage(ing) / workplace SPIRITUALITY human resource(s) / labor /

$$
\text { worker(s) / employee(s) }
$$

SPIRITUAL leadership / intelligence / development

faith / belief/ RELIGION (at / in the) workplace / organization / business / enterprise

RELIGIOUS accommodation / similarity / diversity / expression

Fig. 1 The keywords in the search algorithm 
(2007/01-2017/07) (3) Science Direct (2007/01-2017/07) (4) JSTOR (2007/01-2017/07)

(5) EBSCO (2007/01-2017/07) (6) Google Scholar (2007/01-2017/07).

Selected literature reviews (Sturz and Zografos 2014; Tecchio et al. 2016; Karakas 2010; Balog et al. 2014; Drenten and McManus 2016; Geigle 2012) and three journals (Journal of Management, Spirituality and Religion, Journal of Organizational Change Management and Journal of Management Development) were also searched manually.

\section{Synthesis and Analysis of Outcomes}

Three investigators (LM, PP, AKS) independently: (1) extracted the data, (2) evaluated the study quality, (3) coded and categorized and finally (4) synthesized the findings to answer the review questions.

- The data was extracted by three investigators (LM, PP, AKS) independently using an Excel based data extraction matrix comprising and describing the elements that respond to the objective of this review (Fig. 1. Data extraction matrix). The matrix was developed in accordance with the primary literature search findings.

- The study quality appraisal was done by three independent investigators (LM, PP, AKS) following the QualSyst scoring system for qualitative and quantitative studies (Kmet et al. 2004). Consensus discussions were held to solve any interrater disagreements.

- Two independent investigators (LM, AKS) coded and categorized the findings using the line by line coding to search for research questions, definitions, best practice models and central findings. The derivation of themes was data based.

- LM and PP synthesized the qualitative findings according to the thematic synthesis of qualitative research in systematic reviews (Thomas and Harden 2008). Consensus discussions were held upon presenting the final findings.

\section{Risk of Investigator Bias}

Extensive search of databases was conducted by two independent investigators (PP, LM). Different search strategies and search words/algorithms (sometimes with limitations on site, such as "-books") were applied to exploit the benefits of each search platform. Double checks in reviews, journals, and special issues demonstrated that our online search had included the majority of relevant publications to answer the review questions.

This review concentrates on studies of European origin and focused on literature published only in English. Depending on regional policies, socio-economic situation and local research priorities, the investigated topic may be more relevant in some European countries than in others, and depending on cultural background, scholars may use different concepts and notions having explicit or implicit connection to spirituality and religion.

To diminish investigator bias, an interdisciplinary group of investigators was involved in conducting this review. The investigators are experts in different fields (economics, theology, cultural sciences), know different regions of Europe by origin or longer periods of residence (Eastern Europe, Scandinavia, Germany) and have a number of languages at their 
disposal (English, German, French, Russian, Italian, Finnish, Baltic and Scandinavian). All authors have Christian backgrounds.

\section{Results}

The search results from two independent investigators (PP, LM) were merged using the reference management software Endnote ${ }^{\mathrm{TM}}$. The automatic removal of duplicates resulted in 2331 hits for the preliminary screening. The dual screening of titles and abstracts for eligible studies resulted in identifying 89 studies for the article reading (Fig. 2). During the first read, 17 articles did not meet the primary inclusion criteria linguistically (Rego 2007; Santiago 2007), thematically (Aydinli-Karakulak and Dimitrova 2016; Cornelissen and Jirjahn 2012; Gebert et al. 2014; Gorbănescu 2014; Izak 2015; Kurek and Rachwał 2011; Lloyd and Robinson 2011; Opfinger 2014; Corbett 2009; Essounga-Njan et al. 2013; Ouarda et al. 2012; Schreurs et al. 2014) or contextually (Alidadi and Foblets 2012; Chen and Yeh 2014; Cregård 2017). The reasons for further consensus-based exclusion were:

- three literature reviews (Gundolf and Filser 2013; Silingiene and Skeriene 2016; Tracey 2012);

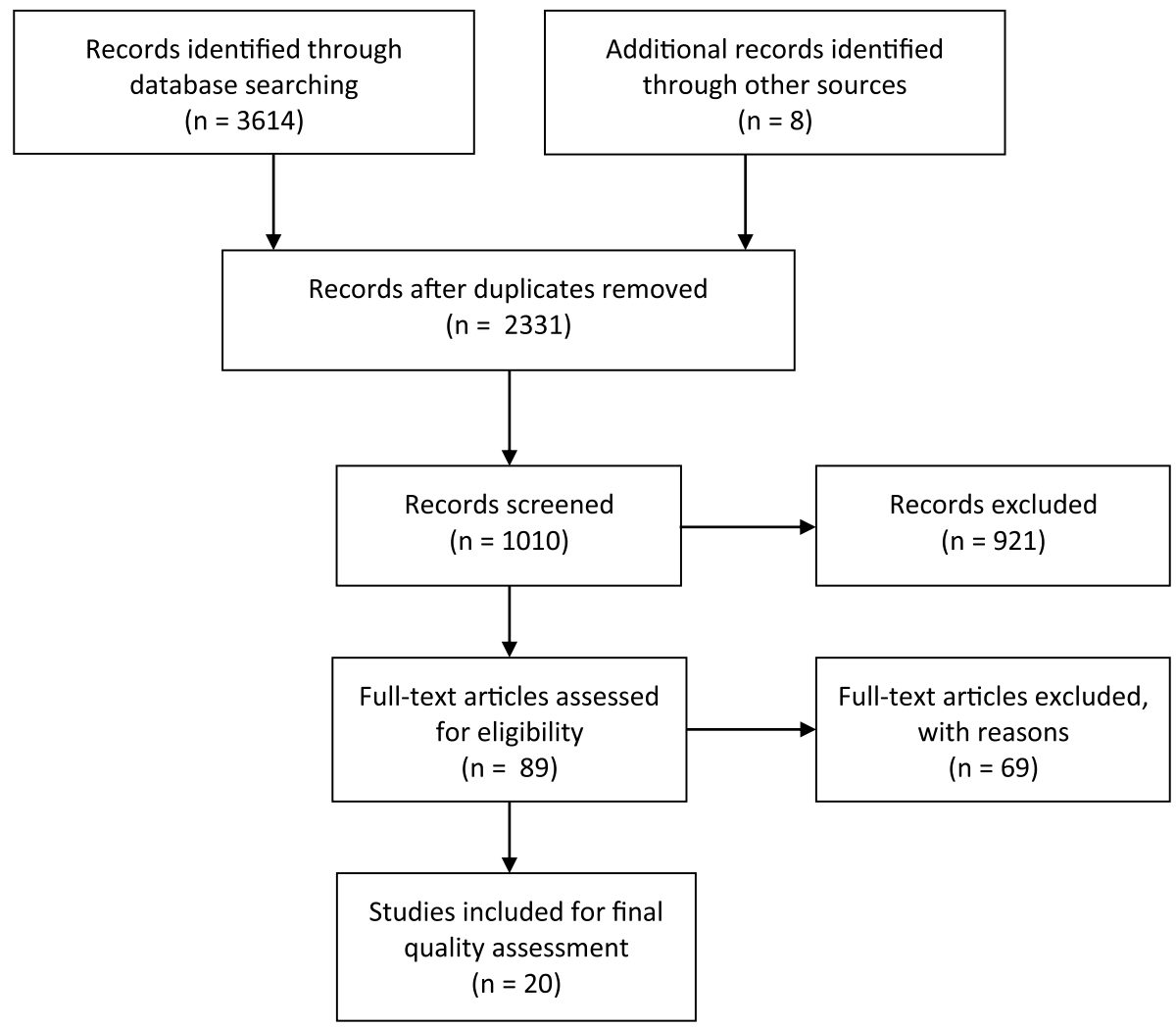

Fig. 2 Flow Diagram 
- 22 conceptual papers (Al Ariss and Sidani 2016; Bolton 2010; Case and Gosling 2010; Corbett 2009; Cullen 2013; Eisenbeiss 2012; Foblets 2013; Kamoche and Pinnington 2012; Krinitcyna and Menshikova 2015; Lennerfors 2015; Nicolae et al. 2013; Roberts 2012; Rozuel 2014; Schnall and Cannon 2012; Slavik et al. 2015; Smith and Rayment 2007; Storsletten and Jakobsen 2015; Szilas 2014; Teeple Hopkins 2015; UngváriZrínyi 2014; Van Gordon et al. 2016; Woniak 2012);

- five articles concentrating on religious branding and consumer behaviour (Paquier 2015; Pace 2013; Rauschnabel et al. 2015; Schlegelmilch et al. 2016; Moraru 2013);

- four RELIGARE studies funded by the European Commission (Foblets and Alidadi 2013; European Commission 2014) monitoring the public sector (Bader et al. 2013; Christoffersen and Vinding 2013; Frégosi and Kosulu 2013; Grekova et al. 2013);

- two articles monitoring the discrimination before entering the workplace (Forstenlechner and Al-Waqfi 2010; Murray and Ali 2017),

- 15 articles from Turkey (Fisher Onar and Müftüler-Baç 2011; Ersoy et al. 2011; Ersoy et al. 2015; Yamak et al. 2015; Dede and Ayranci 2014; Çelik 2012; Sabah et al. 2014; Elçi et al. 2011; Uyar et al. 2015; Kurtulmuş and Warner 2016; Bideci and Albayrak 2016; Altinay 2008; Tanyeri-Erdemir et al. 2013; Karakas and Sarigollu 2017; Kurt et al. 2016) and.

- one conference proceeding (Šilingienè and Škèrienė 2015).

After the careful selection process, 20 studies were eligible to be included for further analysis: two of these are mixed methods (Bakanauskiene and Katiliene 2015; Kupczyk et al. 2015), eight quantitative (Khattab and Johnston 2015; KumpikaitèValiūnienè 2014; Mazereeuw-van der Duijn Schouten et al. 2014; Mensching et al. 2016; Răducan and Răducan 2013a, 2013b; Rego and Pina e Cunha 2008; Volonté 2015) and ten qualitative studies (Cullen and Turnball 2012; Cullen 2011; Pina e Cunha et al. 2017; Izak 2012; Lychnell 2017; Neal and Vallejo 2008; Pio 2010; Stokes et al. 2016; Zaharia and Benchea 2013; Zsolnai and Illes 2017). The studies originate from Romania (3), Poland (2), Lithuania (2), Spain (2), Ireland (2), Sweden (2), United Kingdom (2), Hungary (1), Portugal (1), the Netherlands (1), Switzerland (1) and a German/Swiss/Austrian collaboration (1). The overview of review articles is presented in Table 1.

\section{The Study Quality Appraisal}

Three independent investigators conducted the study quality appraisal following the QualSyst scoring system (Kmet et al. 2004). The score sheet for qualitative studies consists of ten items and the one for quantitative studies, 14 items. In all quantitative studies, the randomizing or blinding interventions (items 5 to 7) were not applicable. Respectively, the maximum score for qualitative studies was $60(3 \times 20)$ (Fig. 3) and for quantitative studies $66(3 \times(28-(3 \times 2)))($ Fig. 4). The two mixed-method studies (Bakanauskiene and Katiliene 2015; Kupczyk et al. 2015) were assessed in both categories.

To reflect on the overall study reporting quality, we looked at the single item reporting quality across the included studies. As each investigator could rate the items with a maximum of two points, each item could be scored with a maximum of six points. For 


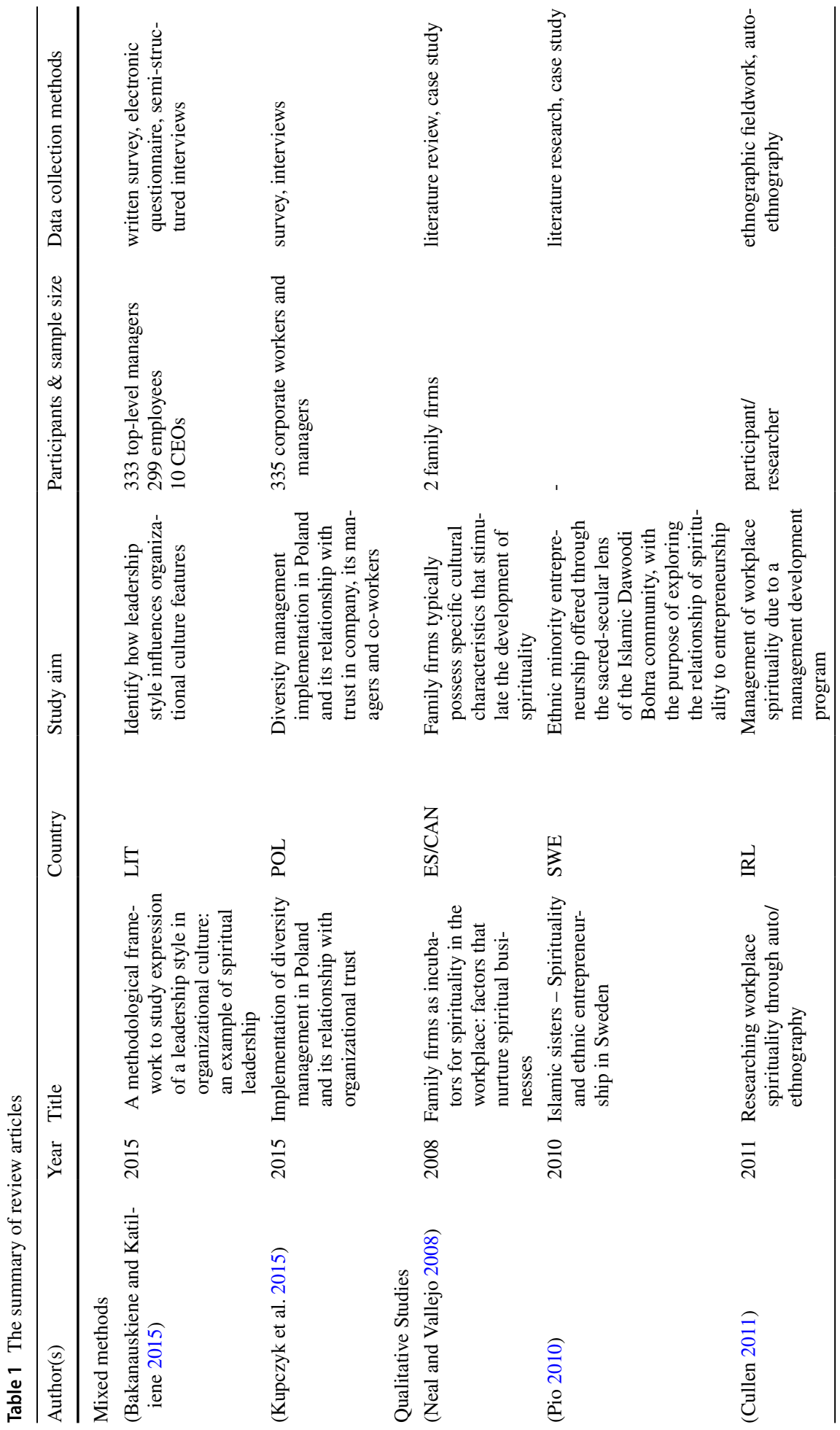




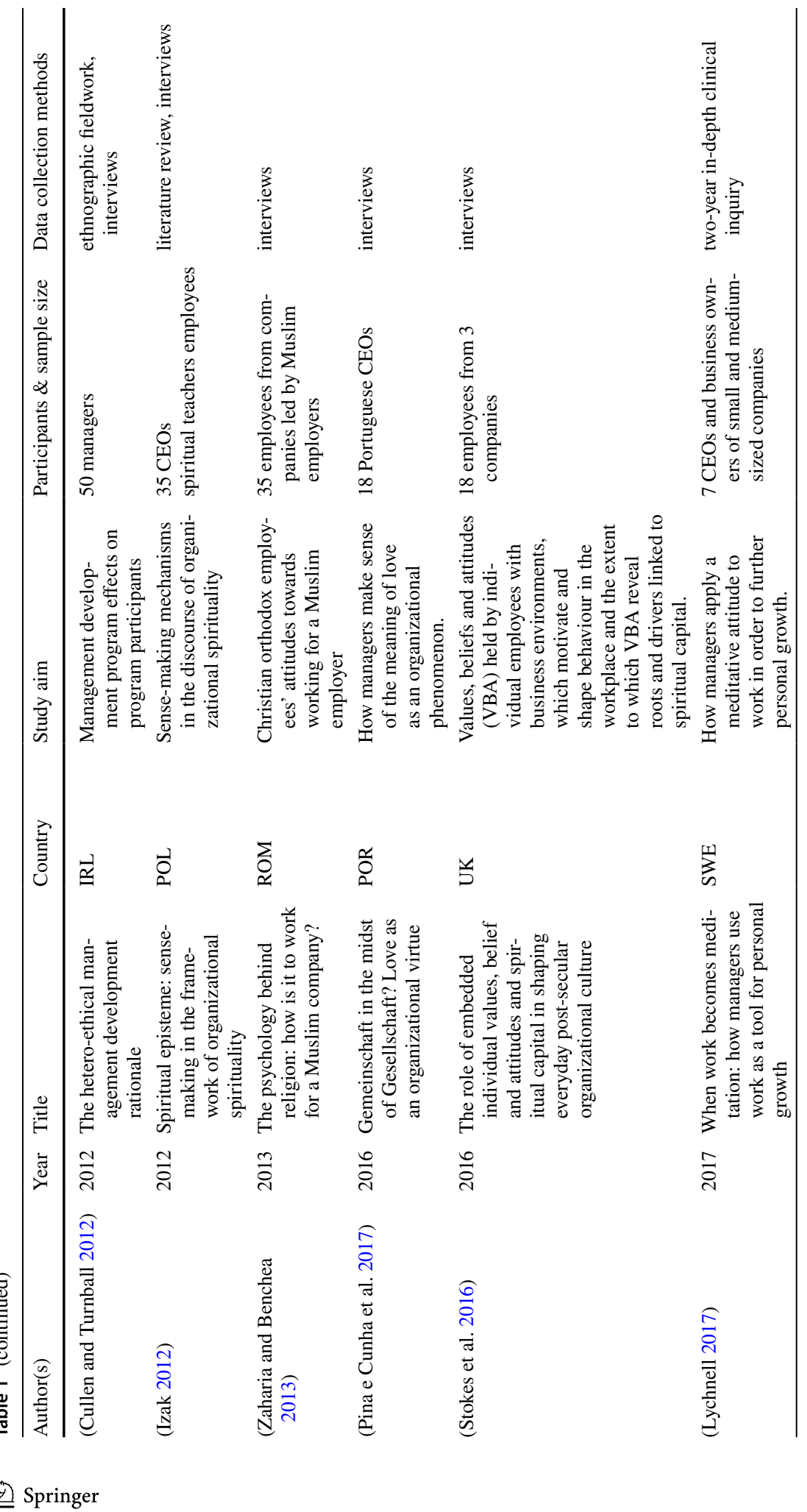




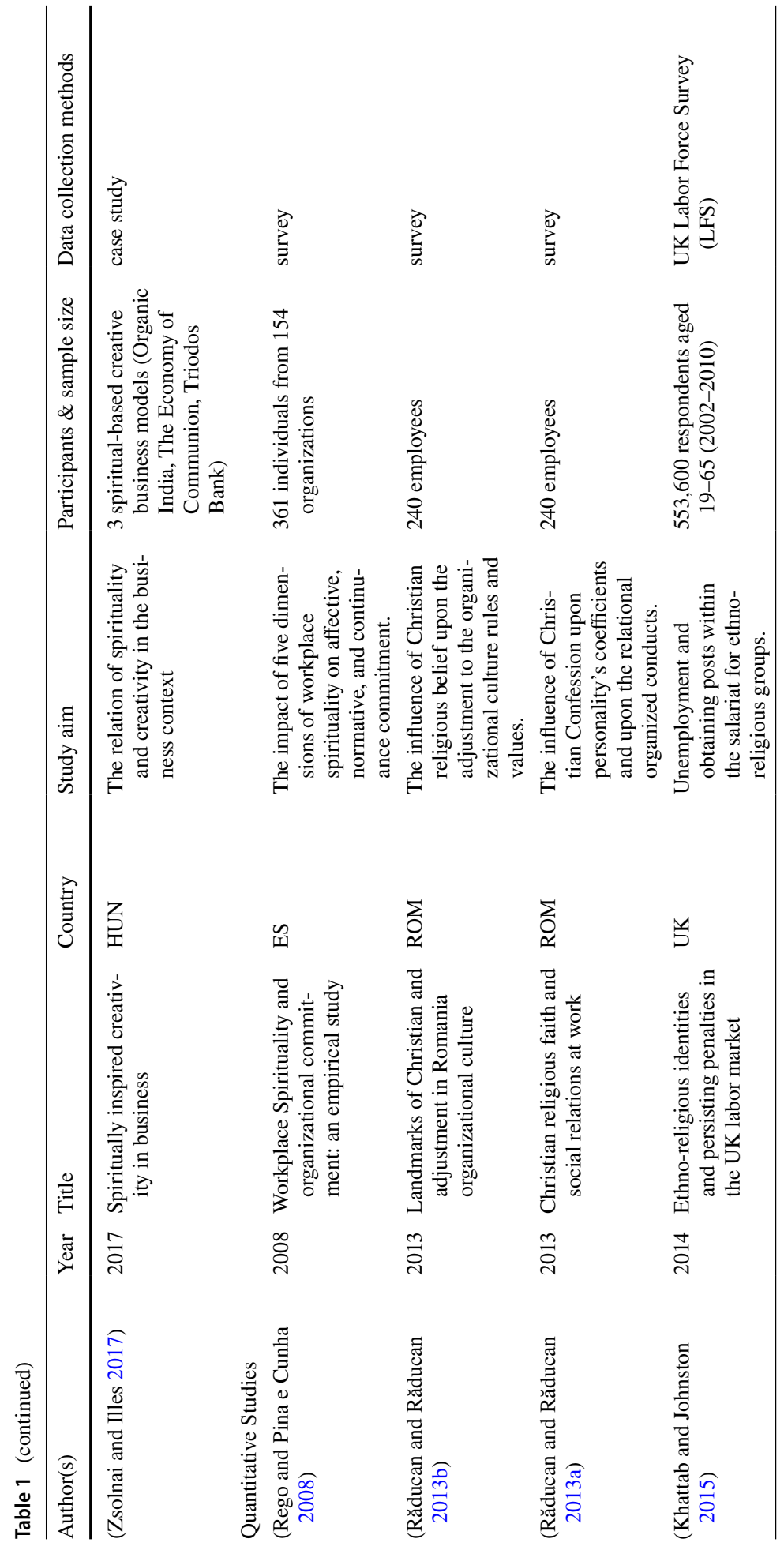




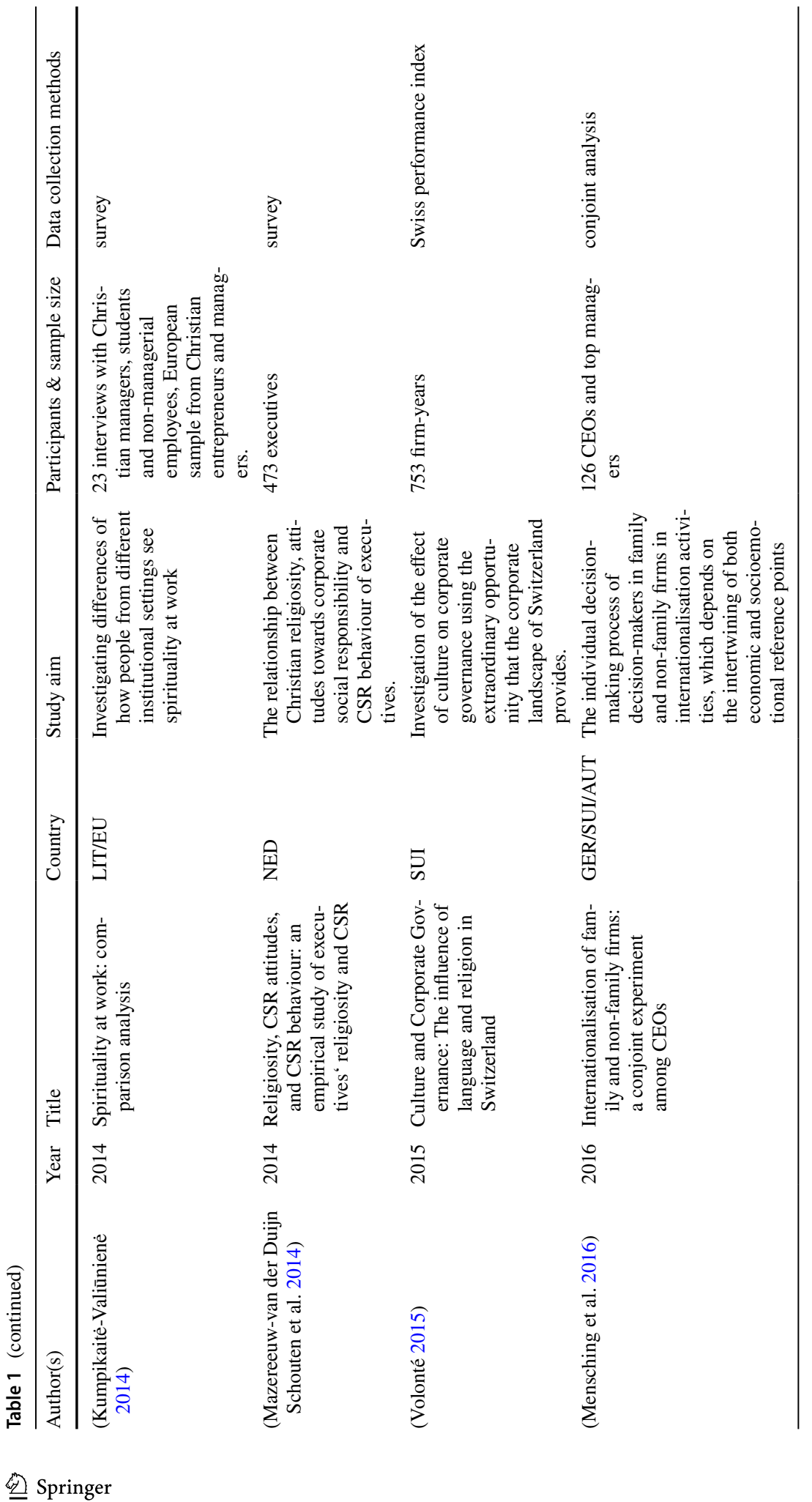




\section{Quality of the Study (max score 60)}

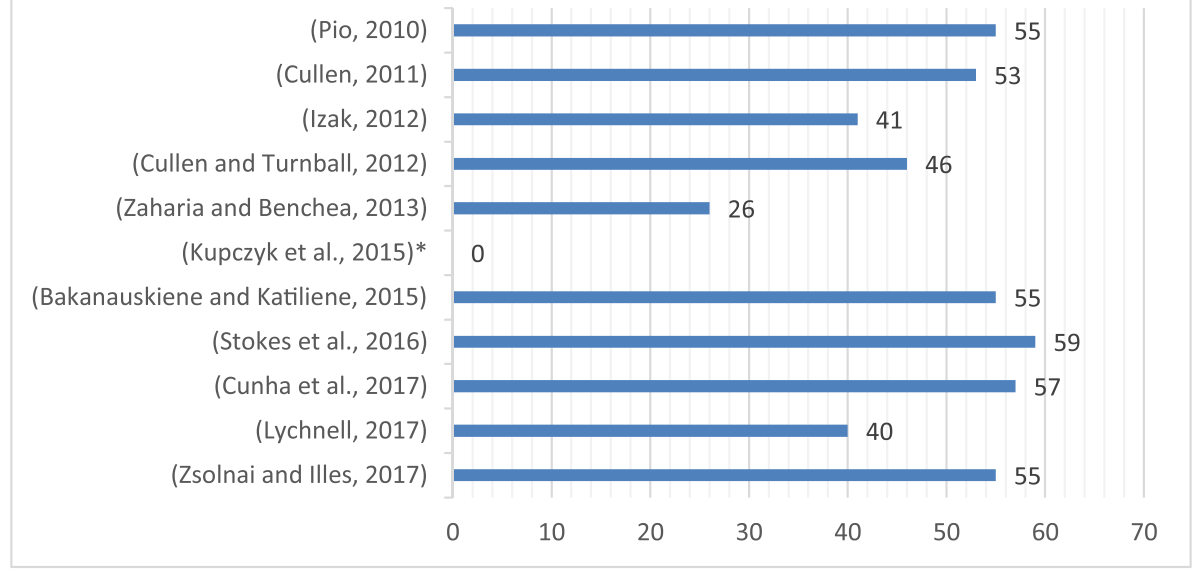

Fig. 3 Quality assessment results for qualitative studies according to the QualSyst scoring system (Kmet et al. 2004). *Kupczyk et al., 2015, conducted a mixed-method study but did not report sufficiently on the qualitative approach, which hindered the quality appraisal

\section{Quality of the Study (max score 66)}

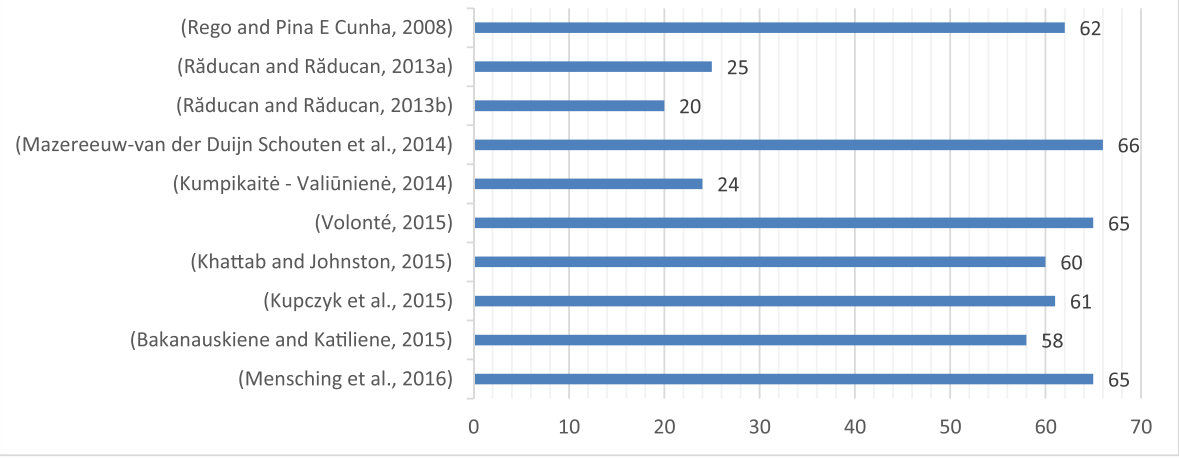

Fig. 4 Quality assessment results for quantitative studies according to the QualSyst scoring system (Kmet et al. 2004)

the analysis, we calculated the average score of each item for both study types, qualitative and quantitative. Qualitative studies (Fig. 5) scored low in items reflecting study design and justifying sampling strategy. Serious flaws were detected in methods applied to data analysis to verify the credibility of outcomes. None of the quantitative studies (Fig. 6) represented randomized controlled studies. Overall the studies failed to justify the participant/ group selection, which led to significant weaknesses in reporting analytic methods and confounders. 


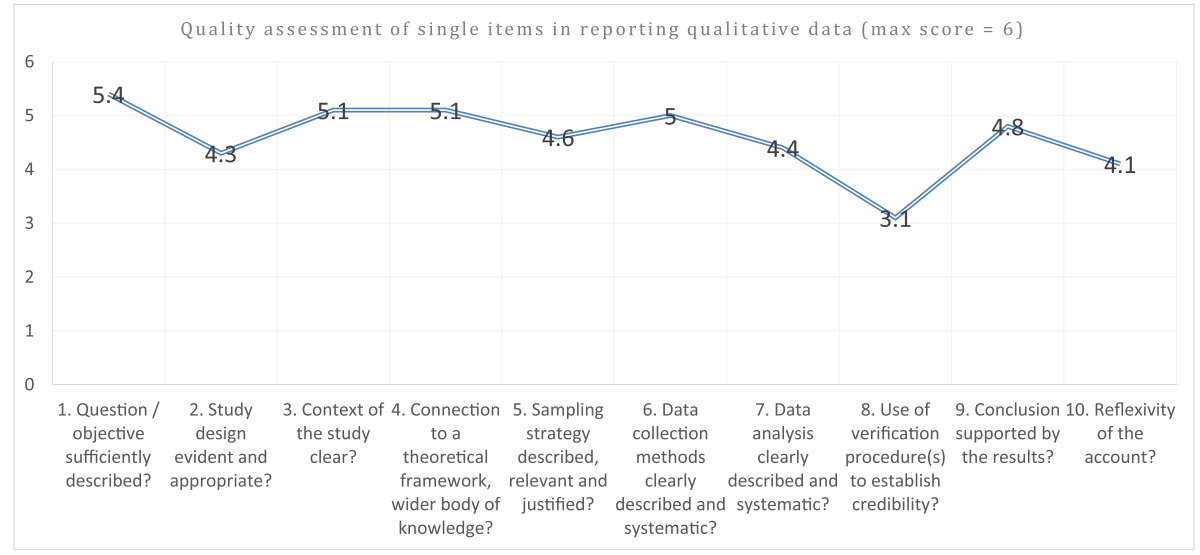

Fig. 5 Quality assessment of single items in reporting qualitative data according to the QualSyst scoring system (Kmet et al. 2004)

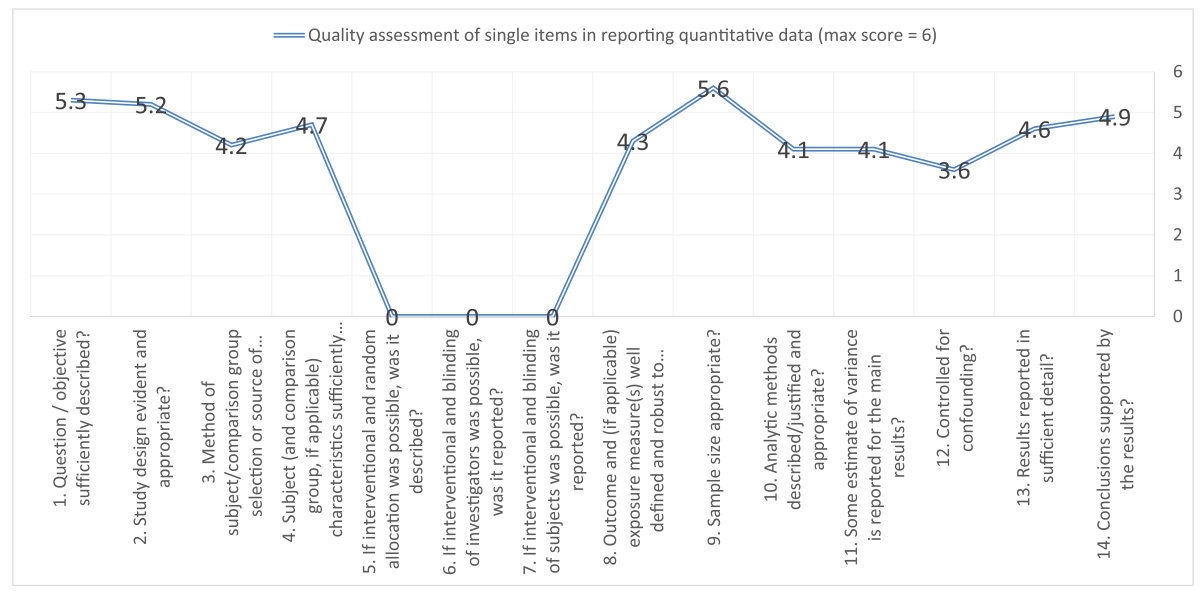

Fig.6 Quality assessment of single items in reporting quantitative data according to the QualSyst scoring system (Kmet et al. 2004)

\section{Synthesis of Thematic Analysis Results}

\section{Question 1: What is Workplace Spirituality?}

There is no consensus regarding the concept of spirituality in the workplace. It is usually not identified with religion or associated with specific religious traditions, but interpreted more broadly (Izak 2012). It can include any ideological or philosophical orientation of values that exist within a company or an employee. Although spirituality is associated with a variety of dimensions and levels ("multidimensional, multilevel phenomenon") (Kumpikaitè-Valiūnienė 2014), two common denominators can be identified: (1) The need and - if successful - the experience of achieving meaningful work that corresponds to one's 
own values, helps others and possibly serves the greater good. (2) The experience of connecting with other people, initially at work and then after work with partners and customers and, if the need arises, over and above creating long-term bonds.

People want to grow personally through their work and make a contribution to society. They want to be connected (,the yearning for connectedness and wholeness") (Izak 2012; Kumpikaitė-Valiūnienè 2014) and desire meaningfulness and happiness (Neal and Vallejo 2008; Cleary et al. 2015; Rego and Pina e Cunha 2008). The connection with the transcendent is explicitly mentioned in different ways (Zsolnai and Illes 2017). Trust among each other is considered to be a central basis (Kupczyk et al. 2015). Spirituality in the workplace, therefore, results in a combined, appealing performance and quality orientation that goes beyond the usual values such as independence, competition and acquisition (Kumpikaitè-Valiūnienè 2014).

The term "spiritual capital" is derived from the organizational and economic context. It was initially chosen by the William Templeton Foundation at the beginning of the 21 st century for "social capital" created by religious communities for the socially disadvantaged. It then was extended to mean "secular" spiritual capital in other contexts, i.e. for the set of values, ethical points of view and visions of individuals as well as of groups and institutions. This includes anything that gives life a sense and meaning, such as relationships of all types. Spiritual capital is considered to be a source of motivation for the other forms of capital in a company (Stokes et al. 2016).

The utilisation of the broad term spirituality for empirical research is the centre of many studies, sometimes combined with an initial empirical evaluation of one's own approach (Bakanauskiene and Katiliene 2015; Rego and Pina e Cunha 2008). Rego and Pina e Cunha identified five dimensions that make both the organizational commitment and the individual meaning of work visible as essential components of workplace spirituality: Experience a sense of community in their work teams, feel that their values are aligned with those of the organization, consider that they do meaningful and helpful work, experience enjoyment at work and consider that the organization gives them opportunities for their inner life (Rego and Pina e Cunha 2008, p. 62-64). Neal and Vallejo have similar aspects for the basis of their study, in that they distinguish the following five dimensions for "Spirit at work": (1) the physical dimension (a positive environment and energy), (2) the affective (a feeling of joy and deep satisfaction of well-being), (3) the cognitive (a feeling of being authentic and a connection of personal values with one's own work and the awareness of doing meaningful work that has a higher goal), (4) the interpersonal (a feeling of connectedness with each other and with a common goal) and (5) the mystical dimension (a spiritual presence, characterized by a feeling of connection with something greater, the transcendence and the experience of inspiration and something sacred). Religion is also considered to be institutionalized spirituality (Neal and Vallejo 2008).

Mazereeuw-van der Duijn Schouten et al. look towards "religiosity". They also describe a complex phenomenon of cognitive, affective-motivational and behavioral aspects, but emphasize institutional integration. Religiosity is "an orienting worldview that is expressed in beliefs, narratives, symbols and practices of worship" (Mazereeuwvan der Duijn Schouten et al. 2014, p. 440). It includes both the inner experience of the individual and the connection with others. For research, they consider it sufficient to choose a few key characteristics, in particular the distinction between intrinsic form (religiosity as a framework for interpreting one's own life) and extrinsic form (dominance of social requirements) (Mazereeuw-van der Duijn Schouten et al. 2014). 
With regard to spirituality in the context of an organization, it is important to distinguish the levels of personal spirituality of employees and organizational spirituality to understand their connection. Hence, the forming of a theoretical foundation based on the various concepts of spirituality as well as on the relationship between organizational structure and spiritual leadership is only in its infancy (Bakanauskiene and Katiliene 2015; Kumpikaitè-Valiūnienė 2014).

\section{Question 2: What Effect Does Workplace Spirituality Have for People and Companies in Profit-oriented Businesses?}

Companies that manage to establish spiritual values have had many positive experiences, both for the individual employee and for the company. For the employees (1) the experience of an appreciative and "spiritual" work environment contributes to a higher emotional well-being and job satisfaction, contentedness and better health (KumpikaitèValiūnienè 2014; Rego and Pina e Cunha 2008; Stokes et al. 2016). (2) This strengthens motivation, willingness to learn, creativity and commitment. Managers and other employees are eager to do their best (Kumpikaitè-Valiūnienè 2014; Rego and Pina e Cunha 2008). It can also lead to courageous activities, e.g. identifying mismanagement or corruption (Stokes et al. 2016). (3) Being respected as a person and accepted as having value orientation leads to a higher degree of emotional and normative commitment to the company.

For the company, on the other hand, (1) the higher affective and normative commitment has a long-term effect on productivity (Rego and Pina e Cunha 2008), whereby (2) rate of return, growth, efficiency and return on investment also increases (KumpikaiteValiūnienè 2014). (3) Overall, there is an improved fit of the person to the organization (Rego and Pina e Cunha 2008). (4) From a functional point of view, this is also an important result since commitment is an influential pre-requisite for organizational and team performance. (5) These forms of commitment are particularly enriching for the change-management of companies and should be taken into account accordingly, so that organizational changes don't conflict with what employees regard as "soft dimensions", described as workplace spirituality (Rego and Pina e Cunha 2008, p. 69).

Global Perspective and Sustainability This value orientation often underlines the need to consider global values, i.e. perspectives with regard to sustainability (Stokes et al. 2016). A solid spiritual foundation is now considered to be one of the important factors in the commitment to sustainability. According to Stokes at al.:

"VBA [Values, Beliefs, Attitudes] makes an often hidden, even mundane, but also very powerful, contribution to human capital. It potentially enhances the value of every member of the company by creating additional conditions and dimensions in which their 'knowledge, capabilities and skills' can be better expressed, thus enhancing their sense of emotional wellbeing and job satisfaction, which in turn minimizes the more destructive and inimical practices that were highlighted within the corporate setting. [...] Second (and linked to the point above), the drivers and application of VBA can be seen to have a multi-levelled impact: from the smallest attention to detail that makes an employee feel valued and noticing another's struggles and engaging empathically, through to standing up of the underdog in the face of perceived miss-management or corruption within the structures of 
the business. Occasionally, VBA highlights the role of business as part of a wider web of interconnectedness that directly connects with global ethical agendas concerning, for example, the well-being of the planet as a whole." (Stokes et al. 2016, p. 48).

Conversely, this means that the prevailing neglect of spirituality hides possible resources for individual and company performance.

\section{Question 3: Risks of Mismanagement of Spirituality in the Workplace}

In the interests of the economy, should individual employees with their diverse cultural backgrounds be placed into the interest of the profit orientation of the business? Cullen $\&$ Turnbull warn against the dangers of "soft capitalism", which puts the whole person in the service of a capitalist company, namely with the neoliberal rhetoric of a new culture of work and organization, the emphasis on self-motivation and self-realization and an authentic self-existence. Such self-centred management development initiatives extend their impact beyond work, to people's aims in life and relationships (Cullen and Turnball 2012).

Approaches to organizational spirituality, which focuses on the congruence of values and the sense of belonging, need political agendas and power structures for their critical corrective analysis. Izak examined some recent studies and questions and their positive aspects of organizational spirituality. He advocates that future research should focus even more on the political aspects, power structures, methods of asserting influence and providing support (Izak 2012). On the other side, an appreciative and "spiritual" work environment can lead employees to courageous activities, e.g. identifying mismanagement or corruption (Stokes et al. 2016).

\section{Question 4: The Contribution of People's Religious Orientation to "spirituality" in the Workplace}

Religion in the workplace has so far been regarded as a diversity factor. Influences beyond this have not yet been investigated much. In the studies at hand, Christianity as a religious background, has formed the basis for this investigation involving a variety of questions. A common result is that religion and spirituality show up at the workplace through various values and attitudes (Mazereeuw-van der Duijn Schouten et al. 2014; Stokes et al. 2016; Zsolnai and Illes 2017).

The studies show that executives and other company employees emphasize the following values: (1) Integrity, sincerity, transparency and trust, (2) reflection on mistakes and constructive criticism of faults, (3) empathy and concern for colleagues, also in an altruistic way instead of constant orientation to fast and inexpensive work, (4) respect and fair dealings with each other and with customers and (5) minimizing hurtful and stressful outcomes. The aim is to compensate for social differences (bridging and linking social capital), build social solidarity and mitigate the dangers of a closed group mentality (Stokes et al. 2016). The focus is on promoting social togetherness as an expression of Christian charity (Mazereeuw-van der Duijn Schouten et al. 2014; Stokes et al. 2016; Zsolnai and Illes 2017). Charity, thus, becomes an organizational principle (Pina e Cunha et al. 2017).

Dealing with Mistakes and Resolution of Conflicts Stokes et al. observe that Christian leaders and company members in the UK find it important to have a culture of dealing with 
mistakes (importance of forgiving), whereas Răducan and Răducan in Romania show a low level of dealing with conflicts and criticism among Orthodox Christian workers (Răducan and Răducan 2013a, 2013b).

Tolerance of Religious Diversity Among Dutch executives, the influence of intrinsic Christian religiosity on the question of diversity was shown to be negative. Traditional Protestant and Catholic teaching and patriarchal ecclesiastical structures are assumed to be the basic reason for this (Mazereeuw-van der Duijn Schouten et al. 2014). In Romania, Orthodox Christianity is considered to be tolerant of religions. Romanians who see themselves as (very) Orthodox Christians have no problem working for a Muslim entrepreneur. In their experience, religion at the workplace is irrelevant and there were no experiences of religious restrictiveness (Zaharia and Benchea 2013).

Impact on Financial Responsibility Mazereeuw-van der Duijn Schouten et al. show a negative effect of intrinsic Christian religiosity in relation to the instrumentalisation of Corporate Social Responsibility (CSR) to maximize profits (Mazereeuw-van der Duijn Schouten et al. 2014). This result is supported by the quotation in many religions: "You cannot serve both God and money" (Luke 16:13).

\section{Special Features: Dependence on Culture and the Religious Composition of the Com-}

pany Board In Swiss companies, confessional-cultural attitudes showed to have an influence on the company's economic and corporate style. In particular, on the willingness to either tolerate company power structures, promote them or influence management and control structures. "Most importantly French, Swiss-French, and Roman Catholics tend to tolerate hierarchical structures and strong leadership. In contrast, German, Swiss-German, and Protestants tend to be skeptical towards a concentration of power" (Volonté 2015, p. 79). The study provides empirical evidence that culture and values related to tolerance for hierarchical structure directly affect board structure: "Swiss-German boards and boards in Protestant cantons are commonly observed to have a two-tiered board structure. [...] In the Swiss-French area and in Roman Catholic cantons, one-tier boards are more prevalent, which necessarily results in concentrations of power" (Volonté 2015, p. 103). The former aim is to limit the concentration of power; the latter promotes it. While the "board composition' is significantly determined by culture, religion and language, ownership as well as capital structure ("equity structure") are not significantly dependent on it (Volonté 2015).

Differences Between West and East The fact that Christian values and a corresponding workplace spirituality contribute to successful company management is a conviction far higher among Christian managers in Western Europe than among Christian blue-collar workers in Lithuania (managers were not interviewed here). A connection with the communist past is suspected to be the reason here (Kumpikaitè-Valiūnienè 2014).

Explicitness of Religion in a Secular Society Religious orientation is frequently not displayed directly, but through values and attitudes. The authors suspect that the obstacles to a secular society, i.e. the hostility towards religious values that religious leaders also notice and feel from non-religious leaders, to be the reasons (Mazereeuw-van der Duijn Schouten et al. 2014). Stokes et al. raise the question of the extent to which this self-censorship is self-imposed, or a consequence of a secular based hostility to religion in the public domain, "whereby only the secular is perceived as neutral and therefore eligible for 
public consumption, and the religious is deemed fit only for private expression (but see also the provision of prayer rooms for staff in many UK firms which contrasts favorably with other EU settings such as in France where work and religion are considered incompatible" (Stokes et al. 2016, p. 49).

\section{Question 5: Religious Diversity and Forms of Discrimination}

The study by Kupczyk et al. notes that the level of diversity management implementation in Poland is rather low. This is related to the fact that trust in organizations is rather low, much lower than trust in management or in colleagues (Kupczyk et al. 2015). Based on the findings of the study by Mazereeuw-van der Duijn Schouten et al. (2014), however, it would be important to know if there is a connection between confidence in organizations and the religious orientation of the managers.

Uncertainties about diversity, especially about other languages and other religions, are greater in family businesses in Germany, Switzerland and Austria than in non-family businesses. Consequently, family businesses in these countries regard internationalisation of their products for more distant countries to be riskier than in the neighbouring countries (Mensching et al. 2016). In the UK, non-white and, especially, Muslim men and women experience discrimination. The discrimination is particularly evident towards higher positions and management levels. "In the case of non-whites, particularly Muslim minorities, there is a clear hierarchy in the penalty they face between the stage of finding a job - any job - and joining the salariat class. This means that through their employment careers some individuals will face an increasing penalty as they seek to advance from a given level to a higher one" (Khattab and Johnston 2015, p. 11-12).

A small case study shows how Muslim women of an ethnic minority (Dawoodi Bohra community) manage to maintain their Islamic identity running their small businesses, even increase their honour in their community and, at the same time, avoid conflict with Sweden's secular host society (Pio 2010).

\section{Question 6: How Can Spirituality be Promoted in For-profit Business? The Importance of Spiritual Leadership}

Promoting workplace spirituality requires new creativity (Šilingienè and Škèrienè 2015; Zsolnai and Illes 2017), a "spiritual intelligence" of managers whose personalities (honesty, appreciation) are committed to ideas and values (including confidence and care), interactions with employees and customers (trust, communication, flexibility, an eye for talent and involvement) and also showing alignment with the performance of a company (life satisfaction, commitment, corporate responsibility, continuous improvement, productivity) (Bakanauskiene and Katiliene 2015).

"Critical existential thinking”, "personal meaning production", "conscious state expansion", "transcendental awareness" are four further characteristics (Šilingienè and Škèrienè 2016, p. 61).

"Spiritual Leadership", which is regarded as a generic term for concepts such as, "business ethics", "values-based leadership" and "corporate social responsibility" brings about a change of perspective by shifting values, e.g. common good before individual capitalist interests, mutual trust before mutual market advantages, social commitment before selfish behaviour and basic needs before subjective preferences. According to Copenhagen 
Business School scholar Peter Pruzan (2011) "spiritually based leadership considers ethics, social responsibility and sustainability not as instruments to protect and promote the classical business rationale, but as fundamental goals in their own right" (Zsolnai and Illes 2017, p. 198). This could create a certain independence, which enables creative and ethically responsible solutions to be found for the complex challenges and goes beyond a purely instrumental rationality and materialistic orientation that contributes to major social and environmental problems (Zsolnai and Illes 2017).

Interventions - Two Examples Researching ways that support people in leadership and management in their spiritual dimension, the studies examined the effects of two rather extensive interventions that pursue conflicting interests. On the one hand, managers were offered possibilities for promoting spiritual development with the aim that their spiritual direction will lead to better corporate values. This showed largely positive results, depending on the spirituality or religiosity of the individual (Cullen 2011). On the other hand, the focus was on how leadership is influenced by a spiritual, or similar, attitude (meditation) and regular experience sharing; this structure gave the individual support so that the participants did not relapse into old work pattern routines (Lychnell 2017).

\section{Discussion}

The global discussion on workplace spirituality and spiritual leadership is ongoing (Altman et al. 2022; Alewell and Moll 2021a, 2021b; Brügger 2021; Moll 2022). World leaders call for value-based decision making in order to guarantee decent work for all and promote sustainable economic growth. The papal Encyclical "Laudato Si'" from 2015 states that "leadership capable of striking out on new paths and meeting the needs of the present with concern for all and without prejudice towards coming generations" (p. 38) is lacking (The Holy Father Francis 2015). In 2015 in New York, world leaders agreed to the key role of decent work for all in achieving sustainable development. This is highlighted by Sustainable Development Goal 8 - SDG 8 - (implemented since 2016) which aims to "promote sustained, inclusive and sustainable economic growth, full and productive employment and decent work for all" (p. 2), including people with disabilities, women, young and older workers, cultural and indigenous minorities as well as migrants. "Furthermore, crucial aspects of decent work are broadly rooted in the targets of many of the other 16 goals" (United Nations 2015, p. 19). Respecting cultural and with that religious diversity as well as personal development and social integration is part of decent workplace practice and calls for special rights and measures at work. Fostering workplace spirituality and religious orientations and expressions at work could be supported by "Good Religious Practice" as SDG 8. Ulrich Hemel of Weltethos-Institut Tübingen proposed this at the UNESCO Summer School in Lucerne in June 2019 to encourage the dialogue between politics, economy and religion (Hemel 2019, p. 250). The research regarding workplace spirituality is concentrated in America, Asia and the Islamic World (Pirkola et al. 2016). Nevertheless, since the turn of the millennium, the subject of workplace spirituality has received greater attention in Europe as well (Zsolnai and Illes 2017).

Following the global call for better and more integrative workplaces, the present systematic review investigated the spiritual dimension in European for-profit-organizations, focusing on explicit religious or spiritual management goals and pondering facilitators and barriers in leveraging R/S in workplace, leadership, and employee bonding. 
Based on the search conducted in a wide range of databases, earlier reviews and peerreviewed journals, our study demonstrates that specific cultural and regional aspects of $\mathrm{R} / \mathrm{S}$ in the workplace are of particular importance in the European context: (1) Individual countries have a different history of "secularity" or "laïcité", and correspondingly, different requirements to address R/S in the workplace. (2) Denomination and religious diversity are defining parameters. (3) The influence of an ex-communist background can also cause divergences.

Of the twenty studies available, eight come from Central and Eastern European countries (Lithuania: 2, Poland: 2, Hungary: 1, Romania: 3), four from the English-speaking region (Ireland: 2; UK: 2), two from Sweden, two from the German-speaking regions (Germany, Austria, Switzerland, incl. French-speaking Switzerland), one from the Netherlands, two from Spain and one from Portugal.

\section{Limitations}

The data were checked in different databases demanding variations in search strategies and algorithms, which affects the transparency and replicability of this systematic review. The search was conducted including literature from 2007/01 to 2017/07. The articles published after 2017/07 are referred to, but not systematically analysed in this paper. A large number of studies were excluded based on pre-defined inclusion/exclusion criteria. By not including the numerous studies conducted in Turkey may have led to implicit bias as there is no comparison of spirituality and religion in the Islamic working worlds. This would, however, be desirable to have in our plural and global work contexts in Europe.

\section{Strengths}

This systematic literature review was reported following the PRISMA guidelines. The study protocol was based on broad preliminary search that was finalized as rigorous search strategy with database appropriate search algorithms and clearly defined inclusion/exclusion criteria. The research questions are specifically focused (Schardt et al. 2007), which is to ensure that the review process remains focused. Three independent investigators were working on screening, data extraction, study quality assessment and thematic analysis at different stages of the process. All included studies are presented according to research design, methodology, data, assumptions made and study quality. Despite the inevitable risks of investigator bias, we believe that the results of this systematic review provide robust evidence and valuable findings for evidence-informed policymaking and encourage a more rigorous research in this field of study.

\section{Conclusions and Recommendations}

The major findings of the research show two different approaches to religion and spirituality $(\mathrm{R} / \mathrm{S})$ in the workplace: (a) Work as a form of self-development and world formation, and, in the broader sense, having spiritual dimensions when associated with the search for meaning and the transcending of oneself. (b) How religious and spiritual orientation becomes allied to the workplace and corporate culture in the form of "spiritual capital".

The spiritual needs of people at work become part of a search for meaningful work that corresponds to their own values, a search for a contribution to society, to the community, to 
responsibility for the whole in the sense of sustainability and for a purpose in life and happiness. The studies show that taking these aspects into account has a positive effect on job satisfaction, health and affective and normative commitment of employees, thereby promoting company productivity and sustainability. According to the studies available, leadership and staff did not openly admit a personal religious orientation towards the Christian faith (only this aspect was available for the studies) as these aspects were hidden in the corporate culture. This proved to have a positive effect through significant commitment to social cohesion and inclusion, but a negative effect through distrust, or at least insecurity, with handling religious diversity. Trust and love were also examined in the framework of principles within an organization. If leadership had a real interest in the spiritual dimension, this would lead to a change of perspective. Maximizing profits would become less important than the values of personal development of employees, greater job satisfaction, bonding and sustainability. However, the studies also point to the danger that, through the concepts of workplace spirituality, people may be exploited for profit-oriented business goals. When looking for work and especially when moving up to higher positions, nonwhite Muslims (both men and women) in particular experience discrimination. In view of the importance of spirituality in the workplace and the growing religious-cultural diversity, the question is raised, whether the time is ripe for religion and spirituality to be taken out of the taboo and private sphere and put into the economic context.

\section{Implications for Evidence-based Policy-making}

In the past, it has been argued that in European societies, R/S has been to a larger extent "privatized" (Luckmann 1996). The concern of counteracting privatization and tabooing and the need to discuss spirituality and religion in the work context, can be understood as an expression of "enlightened respect". "Secularity today does not mean the opposite of religion, but rather, consciously enabling pluralism" (Fiedler 2015, p. 125). Of course, after having been tabooed and privatized for so long, this change requires learning processes, (self-)reflection as well as development of language.

Overall, religion and spirituality are still very much neglected by business enterprises in Europe. Recent studies show that in German-speaking countries, workplace spirituality is less implemented in diversity management and HRM, considering R/S a private matter and being afraid of negative consequences of religions 'violence potential' (Alewell and Rastetter 2020). The findings "suggest that the more businesses can be open to acknowledging the existence of both religious and secular expressions of spiritual capital the more humane and therefore the more productive their corporate environment is likely to be. The more spaces and places in which staff can be facilitated to express their deepest values, beliefs and attitudes for positive change and the well-being, then the more authentically connected they will feel to the roles that have been assigned to them" (Stokes et al. 2016, p. 49). The studies evaluated in this review show the need to differentiate between the spiritual needs that connect many people to their work and work environment and the different cultural and religious backgrounds of the individuals. The question is how spirituality in the workplace is connected to the specific needs of various religions, free space and forms of expression and whether there is time and a place in companies for this. Can promoting workplace spirituality in companies help increase respect for religious diversity in its various forms and can it also help to find creative solutions? 


\section{Implications for Future Research}

Empirical research, as well as theory building and model development for workplace spirituality and spiritual leadership with its connections within Europe to profit-oriented businesses, is still in its initial stage. This, however, should not affect the study quality and the quality of data published. Our review provides suggestions for improvements.

This systematic review presented workplace spirituality as problematic, which indicates that research must be contextualized and the population as well as the methods to investigate R/S and workplace spirituality carefully chosen. It became evident that the available tools to measure R/S and workplace spirituality are not appropriate for the European context. The issue that adequate conceptions and assessment instruments are missing, such as in German-speaking countries, has been raised in other studies (Moll 2020). Albeit other voices, in particularly in the healthcare sector, warn against an instrumentalisation of S/R (Best el al. 2020). Further investigations of the connection of workplace spirituality and $\mathrm{R} / \mathrm{S}$ with social determinants and health (e.g. based on absenteeism) is also needed. In particular, long-term studies and studies with control groups are entirely missing.

Author Contributions LM and EF devised the project and the main conceptual ideas. LM and PP performed the preliminary and final literature search. PP worked out the study protocol. LM, PP and AKS extracted the data and preformed the quality assessment. LM and PP wrote the manuscript. All authors contributed to the article and approved the submitted version.

Funding Open Access funding enabled and organized by Projekt DEAL. This work was supported by Karl Schlecht Stiftung.

Data Availability The datasets generated and/or analysed during the current study are available from the corresponding author on reasonable request.

Code Availability The search and data extraction strategy is presented in the paper.

\section{Declarations}

Conflict of Interest The authors confirm that there is no conflict of interest.

Open Access This article is licensed under a Creative Commons Attribution 4.0 International License, which permits use, sharing, adaptation, distribution and reproduction in any medium or format, as long as you give appropriate credit to the original author(s) and the source, provide a link to the Creative Commons licence, and indicate if changes were made. The images or other third party material in this article are included in the article's Creative Commons licence, unless indicated otherwise in a credit line to the material. If material is not included in the article's Creative Commons licence and your intended use is not permitted by statutory regulation or exceeds the permitted use, you will need to obtain permission directly from the copyright holder. To view a copy of this licence, visit http://creativecommons.org/licenses/by/4.0/.

\section{References}

Ahmed, Adeel, Mohd Anuar Arshad, Arshad Mahmood, and Sohail Akhtar. 2016. Holistic Human Resource Development: Balancing the Equation through the Inclusion of Spiritual Quotient. Journal of Human Values 22 (3): 165-179. https://doi.org/10.1177/0971685816650573.

Alcázar, Fernando Martín, Pedro Miguel Romero Fernández, and Gonzalo, Sánchez Gardey. 2013. Workforce diversity in strategic human resource management models: A critical review of the literature and implications for future research. Cross Cultural Management 20 (1): 39-49. https://doi.org/10.1108/ 13527601311296247. 
Alewell, Dorothea, and Tobias Moll. 2021a. An Exploratory Study of Spirituality in German Enterprises. Management Revue - Socio-Economic Studies 32(1): 1-27. https://doi.org/10.5771/ 0935-9915-2021-1-

Alewell, Dorothea, and Tobias Moll. 2021b. Employers' strategies on faith at work. In Routledge studies in management, organizations and society. Reimagining faith and management: The impact of faith in the workplace, ed. Edwina Pio, R. Kilpatrick, and T. Pratt, 117-130. Routledge. https://doi.org/10. 4324/9781003041733-11

Alewell, Dorothea, and Daniela Rastetter. 2020. On the (ir)relevance of religion for human resource management and diversity management: A German perspective. German Journal of Human Ressource Management 34(1): 9-31. https://doi.org/10.1177/2397002219882399

Alidadi, Kathleen, and Marie-Claire Foblets. 2012. Framing multicultural challenges in freedom of religion terms. Netherlands Quarterly of Human Rights 30 (4): 388-416.

Altman, Yochanan, Judi Neal, and Wolfgang Mayrhofer (eds). 2022. Workplace Spirituality. Making a Difference. Berlin: DeGruyter.

Alsaker, Kjersti, Bente E Moen, Valborg Baste, and Tone Morken. 2016. How has living with intimate partner violence affected the work situation? A qualitative study among abused women in Norway. Journal of Family Violence 31 (4): 479-487.

Altinay, Levent. 2008. The relationship between an entrepreneur's culture and the entrepreneurial behaviour of the firm. Journal of Small Business and Enterprise Development 15 (1): 111-129. https:// doi.org/10.1108/14626000810850874.

Ameli, Saied Reza, and Hamideh Molaei. 2012. Religious affiliation and intercultural sensitivity: Interculturality between Shia \& Sunni Muslims in Iran. International Journal of Intercultural Relations 36 (1): 31-40. https://doi.org/10.1016/j.ijintrel.2010.11.007.

Antwi, Enoch. 2017. Leadership Is Concept Heavy: A Case Against Fragmented Theories in Evolutionary and Contemporary Leadership. Bloomington: AuthorHouse.

Al Ariss, Akram, and Yusuf M. Sidani. 2016. Understanding religious diversity: Implications from Lebanon and France. Cross Cultural and Strategic Management 23 (3): 467-480. https://doi.org/10. 1108/CCSM-02-2015-0020.

Arnetz, Bengt B., Matthew Ventimiglia, Pamela Beech, Valerie DeMarinis, Johan Lökk, and Judith E. Arnetz. 2013. Spiritual values and practices in the workplace and employee stress and mental well-being. Journal of Management, Spirituality and Religion 10 (3): 271-281. https://doi.org/10. 1080/14766086.2013.801027.

Ashforth, Blake E., and Deepa Vaidyanath. 2002. Work organizations as secular religions. Journal of Management Inquiry 11 (4): 359-370.

Aydinli-Karakulak, Arzu, and Radosveta Dimitrova. 2016. Brief report: When does identity lead to negative affective experiences? A comparison of Turkish-Bulgarian and Turkish-German adolescents. Journal of Adolescence 47: 125-130. https://doi.org/10.1016/j.adolescence.2015.09.010.

Bader, Veit, Katayoun Alidadi, and Floris Vermeulen. 2013. Religious diversity and reasonable accommodation in the workplace in six European countries: An introduction. International Journal of Discrimination and the Law 13 (2-3): 54-82. https://doi.org/10.1177/1358229113493691.

Bakanauskiene, Irena, and Rasa Katiliene. 2015. A methodological framework to study the expression of a leadership style in organizational culture: An example of spiritual leadership. Problems and Perspectives in Management 13 (1): 185-196 and 129.

Balog, Angela M., LaKami T Baker, and Alan G. Walker. 2014. Religiosity and spirituality in entrepreneurship: A review and research agenda. Journal of Management, Spirituality and Religion 11 (2): 159-186. https://doi.org/10.1080/14766086.2013.836127.

Bark, Alina S. Hernandez, Jordi Escartín, and Rolf van Dick. 2014. Gender and leadership in Spain: A systematic review of some key aspects. Sex Roles 70 (11-12): 522-537.

Baumane-Vītolina, Ilona, Madara Apsalone, Erika Sumilo, and Krista Jaakson. 2017. Ethical behaviour and honesty in post-Soviet business environment. Baltic Journal of Management 12 (1): 46-62. https://doi.org/10.1108/BJM-02-2016-0052.

Belhassen, Yaniv, and Amir Shani. 2012. Hotel workers' substance use and abuse. International Journal of Hospitality Management 31 (4): 1292-1302.

Best, Megan, Carlo Leget, Andrew Goodhead, and Piret Paal. 2020. An EAPC white paper on multidisciplinary education for spiritual care in palliative care. BMC Palliative Care 19: 9. https://doi. org/10.1186/s12904-019-0508-4.

Bideci, Müjde, and Tahir Albayrak. 2016. Motivations of the Russian and German tourists visiting pilgrimage site of Saint Nicholas Church. Tourism Management Perspectives 18: 10-13. https://doi. org/10.1016/j.tmp.2015.12.022. 
Bolton, Sharon C. 2010. Being human: Dignity of labor as the foundation for the spirit-work connection. Journal of Management, Spirituality and Religion 7 (2): 157-172. https://doi.org/10.1080/14766 081003746422.

Borstorff, Patricia, and K. Arlington. 2011. Protecting religion in the workplace? What employees think. Journal of Legal, Ethical and Regulatory Issues 14 (1): 59-70.

Brown, Michelle, Rowan Minson, Ann O'Connell, and Ian Ramsay. 2012. Employee participation in employee share ownership plans: The law, company objectives and employee motives. Australian Journal of Labour Law 25 (1): 1-22.

Brügger, Tobias. 2021. The Christian body at work. Spirituality, embodiment, and Christian living. Baden-Baden: Nomos. https://doi.org/10.5771/9783748922629

Byrne, Conor J, Dana M. Morton, and Jason J. Dahling. 2011. Spirituality, religion, and emotional labor in the workplace. Journal of Management, Spirituality and Religion 8 (4): 299-315.

Case, Peter, and Jonathan Gosling. 2010. The spiritual organization: critical reflections on the instrumentality of workplace spirituality. Journal of Management, Spirituality and Religion 7 (4): 257-282.

Çelik, Duysal Aşkun. 2012. For creating unity and oneness in organizations: Understanding oneness behaviors in organizations from the perspective of integrative self-knowledge and organizational citizenship behavior. Purusharta 5 (1): 71-85.

Charles, Ginger. 2016. Leadership Resilience: Lessons for Leaders from the Policing Frontline. Abingdon-on-Thames: Routledge.

Chawla, Deepak, Afsha Dokadia, and Snigdha Rai. 2017. Multigenerational differences in career preferences, reward preferences and work engagement among Indian employees. Global Business Review 18 (1): 181-197.

Chen, Daniel L., and Susan Yeh. 2014. The construction of morals. Journal of Economic Behavior \& Organization 104: 84-105. https://doi.org/10.1016/j.jebo.2013.10.013.

Christoffersen, Lisbet, and Vinding Niels Valdemar. 2013. Challenged pragmatism. International Journal of Discrimination and the Law 13 (2-3): 140-168. https://doi.org/10.1177/1358229113492064.

Cleary, James, Hellen Gelband, and Judith Wagner. 2015. Cancer Pain Relief. In Cancer: Disease Control Priorities, Third Edition (Volume 3). Washington (DC): eds. Hellen Gelband, Prabhat Jha, Rengaswamy Sankaranarayanan, Susan Horton.

Corbett, Matrin J. 2009. Invoking spirits in the material world: Spiritualism, surrealism, and spirituality at work. Management and Organizational History 4 (4): 339-357. https://doi.org/10.1177/17449 35909340189.

Cornelissen, Thomas, and Uwe Jirjahn. 2012. Religion and earnings: Is it good to be an atheist with religious parental background? Economics Letters 117 (3): 905-908. https://doi.org/10.1016/j.econl et.2012.07.013.

Cregård, Anna. 2017. Investigating the Risks of Spiritual Leadership. Nonprofit Management and Leadership 27 (4): 533-547. https://doi.org/10.1002/nml.21262.

Cullen, John G. 2011. Researching workplace spiritualization through auto/ethnography. Journal of Management, Spirituality and Religion 8 (2): 143-164. https://doi.org/10.1080/14766086.2011.581813.

Cullen, John G., and Sharon R. Turnball. 2012. The "hetero-ethical" management development rationale. Journal of Management Development 31 (6): 584-593. https://doi.org/10.1108/0262171121 1230876.

Cullen, John G. 2013. Vocational ideation and management career development. Journal of Management Development 32 (9): 932-944. https://doi.org/10.1108/JMD-09-2012-0125.

Dede, Nurten Polat, and Evren Ayranci. 2014. Exploring the connections among spiritual leadership, altruism, and trust in family businesses. Quality and Quantity 48 (6): 3373-3400. https://doi.org/ 10.1007/s11135-013-9962-x.

Dent, Eric B, M Eileen Higgins, and Deborah Wharff. 2005. Spirituality and leadership: An empirical review of definitions, distinctions, and embedded assumptions. The Leadership Quarterly 16 (5): 625-653.

Drenten, Jenna, and Kristy McManus. 2016. Religion-Related Research in the Journal of Macromarketing, 1981-2014. Journal of Macromarketing 36 (4): 377-387. https://doi.org/10.1177/0276146715 623051.

Eisenbeiss, Silke Astrid. 2012. Re-thinking ethical leadership: An interdisciplinary integrative approach. Leadership Quarterly 23 (5): 791-808. https://doi.org/10.1016/j.leaqua.2012.03.001.

Elçi, Meral, İrge Sener, and Lütfihak Alpkan. 2011. The Impact of Morality and Religiosity of Employees on Their Hardworking Behavior. Procedia - Social and Behavioral Sciences 24: 1367-1377. https://doi.org/10.1016/j.sbspro.2011.09.135. 
Ersoy, Cem Nevra, Marise Ph. Born, Eva Derous, and Henk T. van der Molen. 2011. Antecedents of organizational citizenship behavior among blue- and white-collar workers in Turkey. International Journal of Intercultural Relations 35 (3): 356-367. https://doi.org/10.1016/j.ijintrel.2010.05.002.

Ersoy, Nevra Cem, Eva Derous, Marise Ph. Born, and Henk T. van der Molen. 2015. Antecedents of organizational citizenship behavior among Turkish white-collar employees in The Netherlands and Turkey. International Journal of Intercultural Relations 49: 68-79. https://doi.org/10.1016/j.ijint rel.2015.06.010.

Essounga-Njan, Yvette, Helisse Levine, Ning Ding, and Samuel Mercier. 2013. Leadership and spirituality in business and public administration: A cross-cultural empirical study comparing the USA and France. International Journal of Services and Standards 8 (4): 295-314. https://doi.org/10. 1504/IJSS.2013.058220.

European Commission. 2014. Religious Diversity and Secular Models in Europe - Innovative Approaches to Law and Policy. https://cordis.europa.eu/project/id/244635/reporting. Accessed 23 Sept 2017.

Farina, Salvatore E. 2015. Leadership development coaching: Best practices for improving performance in crafting vision, building alignment, and championing implementation. Assemblies of God Theological Seminary.

Fiedler, Adelheid. 2015. Aufgeklärter Respekt - Säkularität als Beratungshaltung. Gruppendynamik und Organisationsberatung 46: 125-135.

Fisher Onar, Nora, and Meltem Müftüler-Baç. 2011. The adultery and headscarf debates in Turkey: Fusing "EU-niversal" and "alternative" modernities? Women's Studies International Forum 34 (5): 378-389. https://doi.org/10.1016/j.wsif.2011.04.009.

Foblets, Marie-Claire. 2013. Freedom of religion and belief in the European workplace: Which way forward and what role for the European Union? International Journal of Discrimination and the Law 13 (2-3): 240-255. https://doi.org/10.1177/1358229113504350.

Foblets, Marie-Claire, and Katie Alidadi. 2013. Summary report an the RELIGARE projekt Summer 2013. https://cordis.europa.eu/docs/results/244635/final1-religare-final-publishable-report-nov-2013-wordversion.pdf. Accessed 23 Sept 2017.

Forstenlechner, Ingo, and Mohammed A. Al-Waqfi. 2010. "A job interview for Mo, but none for Mohammed": Religious discrimination against immigrants in Austria and Germany. Personnel Review 39 (6): 767-784. https://doi.org/10.1108/00483481011075602.

Frégosi, Franck, and Denisz Kosulu. 2013. Religion and religious discrimination in the French workplace: Increasing tensions, heated debates, perceptions of labour unionists and pragmatic best practices. International Journal of Discrimination and the Law 13 (2-3): 194-213. https://doi.org/10.1177/ 1358229113493693.

Fry, Louis W., and Yochana Altman. 2013. Spiritual leadership in Action: the cel story achieving extraordinary results through ordinary people. IAP.

Gallardo-Gallardo, Eva, Marian Thunnissen, and Hugh Scullion. 2020. Talent management: context matters. The International Journal of Human Resource Management 31 (4): 457-473. https://doi.org/10. 1080/09585192.2019.1642645.

Gebert, Diether, Sabine Boerner, Eric Kearney, James E King Jr, Kai Zhang, and Lynda Jiwen Song. 2014. Expressing religious identities in the workplace: Analyzing a neglected diversity dimension. Human Relations 67 (5): 543-563. https://doi.org/10.1177/0018726713496830.

Geigle, David. 2012. Workplace spirituality empirical research: A literature review. Business and Management Review 2 (10): 14-27.

Ghumman, Sonia, Ann Marie Ryan, Lizabeth A. Barclay, and Karen S. Markel. 2013. Religious Discrimination in the Workplace: A Review and Examination of Current and Future Trends. Journal of Business and Psychology 28 (4): 439-454.

Gorbănescu, Adrian. 2014. Job Relocation Prediction. Procedia - Social and Behavioral Sciences 127: 650654. https://doi.org/10.1016/j.sbspro.2014.03.329.

Grekova, Maya, Iva Kyurkchieva, and Maya Kosseva. 2013. Accommodation of religious diversity at the workplace through the prism of state-religion relations: The Bulgarian Case. International Journal of Discrimination and the Law 13 (2-3): 169-193. https://doi.org/10.1177/1358229113 489397.

Gundolf, Katherine, and Matthias Filser. 2013. Management Research and Religion: A Citation Analysis. Journal of Business Ethics 112 (1): 177-185. https://doi.org/10.1007/s10551-012-1240-7.

Habib Rana, M., and M. Shaukat Malik. 2016. Human resource management from an Islamic perspective: a contemporary literature review. International Journal of Islamic and Middle Eastern Finance and Management 9 (1): 109-124. https://doi.org/10.1108/IMEFM-01-2015-0002. 
Hashim Jameelah Maryam, Idris Osman, and Syed Musa Alhabshi. 2015. Effect of Intellectual Capital on Organizational Performance. Procedia - Social and Behavioral Sciences 211: 207-214. https://doi. org/10.1016/j.sbspro.2015.11.085.

Hemel, Ulrich. 2019. Dank und Ausblick: Zur Umsetzug von "Weltethos" im 21. Jahrhundert. In Weltethos für das 21. Jahrhundert, ed. Ulrich Hemel, 249-253. Freiburg i.Br.: Herder-Verlag.

Hogan, Anthony, Su Mon Kyaw-Myint, Debra Harris, and Harmony Denronden. 2012. Workforce participation barriers for people with disability. International Journal of Disability Management 7: 1-9.

Izak, Michal. 2012. Spiritual episteme: Sensemaking in the framework of organizational spirituality. Journal of Organizational Change Management 25 (1): 24-47. https://doi.org/10.1108/095348112111995 83.

Izak, Michal. 2015. Learning from a fool: Searching for the 'unmanaged' context for radical learning. Management Learning 46 (1): 87-104. https://doi.org/10.1177/1350507613486426.

Kamoche, Ken, and H Pinnington Ashly. 2012. Managing people 'spiritually': a Bourdieusian critique. Work, employment and society 26 (3): 497-513. https://doi.org/10.1177/0950017012438573.

Karakas, Fahri, and Emine Sarigollu. 2017. Spirals of Spirituality: A Qualitative Study Exploring Dynamic Patterns of Spirituality in Turkish Organizations. Journal of business ethics 156 (2): 799-821. https:// link.springer.com/article/10.1007/s10551-017-3619-y. Accessed 13 November 2017.

Karakas, Fahri. 2010. Spirituality and performance in organizations: A literature review. Journal of business ethics 94 (1): 89-106.

Kaufmann, Lutz, and Julia Gaeckler. 2015. A structured review of partial least squares in supply chain management research. Journal of Purchasing and Supply Management 21 (4): 259-272. https://doi.org/ 10.1016/j.pursup.2015.04.005.

Kaufmann, Lutz, and Claudia M. Wagner. 2017. Affective diversity and emotional intelligence in crossfunctional sourcing teams. Journal of Purchasing and Supply Management 23 (1): 5-16. https://doi. org/10.1016/j.pursup.2016.07.004.

Khattab, Nabil, and Ron Johnston. 2015. Ethno-religious identities and persisting penalties in the UK labor market. The Social Science Journal 52 (4): 490-502. https://doi.org/10.1016/j.soscij.2014. 10.007 .

Kmet, Leanne M., Robert C. Lee, and Linda S. Cook. 2004. Standard Quality Assessment Criteria for Evaluating Primary Research Papers from a Variety of Fields. Alberta: Edmonton.

Köllen, Thomas. 2016. Sexual orientation and transgender issues in organizations. Global Perspectives on LGBT Workforce Diversity. Berlin: Springer.

Krinitcyna, Zoya V., and Ekaterina V. Menshikova. 2015. Discrimination Issues in the Process of Personnel Selection. Procedia - Social and Behavioral Sciences 166: 12-17. https://doi.org/10.1016/j. sbspro.2014.12.475.

Kulik, Carol T. 2014. Working below and above the line: The research-practice gap in diversity management. Human Resource Management Journal 24 (2): 129-144. https://doi.org/10.1111/1748-8583. 12038.

Kulkarni, Mukta, and Caren Rodrigues. 2014. Engagement with disability: Analysis of annual reports of Indian organizations. The International Journal of Human Resource Management 25 (11): 1547-1566.

Kumpikaitè-Valiūnienè, Vilmantè. 2014. Spirituality at Work: Comparison Analysis. Procedia - Social and Behavioral Sciences 150: 1205-1212. https://doi.org/10.1016/j.sbspro.2014.09.136.

Kupczyk, Teresa, Aneta Klaudia Szymańska, Joanna Kubicka, and Anna Oleszkiewicz. 2015. Implementation of diversity management in Poland and its relationship with organizational trust. International Journal of Organizational Diversity 15 (4): 17-27.

Kurek, Sławomir, and Tomasz Rachwał. 2011. Development of entrepreneurship in ageing populations of The European Union. Procedia - Social and Behavioral Sciences 19: 397-405. https://doi.org/ 10.1016/j.sbspro.2011.05.147.

Kurt, Yusuf, Mohammad Yamin, Noemi Sinkovics, and Robert R. Sinkovics. 2016. Spirituality as an antecedent of trust and network commitment: The case of Anatolian Tigers. European Management Journal 34 (6): 686-700. https://doi.org/10.1016/j.emj.2016.06.011.

Kurtulmuş, Bekir Emre, and Bernadette Warner. 2016. Informal institutional framework and entrepreneurial strategic orientation: The role of religion. International Journal of Entrepreneurship and Innovation Management 20 (3-4): 160-173. https://doi.org/10.1504/IJEIM.2016.077959.

Lalani, Moiz. 2014. Exploring the Role of Responsible Leadership in Business and Industry. Phoenix: Grand Canyon University.

Lazarova, Mila, Mina Westman, and Margaret A. Shaffer. 2010. Elucidating the positive side of the work-family interface on international assignments: A model of expatriate work and family performance. Academy of Management Review 35 (1): 93-117. 
Lennerfors, Thomas Taro. 2015. A Buddhist future for capitalism? Revising Buddhist economics for the era of light capitalism. Futures 68: 67-75. https://doi.org/10.1016/j.futures.2014.09.003.

Levay, Charlotta. 2014. Obesity in organizational context. Human Relations 67 (5): 565-585.

Lizardo, Omar. 2011. Review of Spiritual economies: Islam, globalization, and the afterlife of development. Administrative Science Quarterly 56 (3): 485-489. https://doi.org/10.1177/0001839212 437698.

Lloyd, Katrina, and Gillian Robinson. 2011. Intimate mixing - bridging the gap? Catholic-Protestant relationships in Northern Ireland. Ethnic and Racial Studies 34 (12): 2134-2152. https://doi.org/ 10.1080/01419870.2011.574716.

Luckmann, Thomas. 1996. Privatization of religion and morals. In Detraditionalization. Crititical reflections on authority and identity, eds. Paul Heelas, Scott Lash, and Paul Morris, 72-86. Oxford: Oxford University Press.

Lychnell, Lasse. 2017. When work becomes meditation: how managers use work as a tool for personal growth. Journal of Management, Spirituality and Religion: 1-21. https://doi.org/10.1080/14766 086.2017.1307782.

Marshall, J Alan. 2012. Ethical leadership, prototypicality, integrity, trust, and leader effectiveness. Virginia Beach: Regent University.

Martin, Thomas N., and John C. Hafer. 2009. Models of emotional intelligence, spiritual intelligence, and performance: a test of Tischler, Biberman, and McKeage. Journal of Management, Spirituality \& Religion 6 (3): 247-257. https://doi.org/10.1080/14766080903069364.

Mazereeuw-van der Duijn Schouten, Corrie, Johan Graafland, and Muel Kaptein. 2014. Religiosity, CSR Attitudes, and CSR Behavior: An Empirical Study of Executives' Religiosity and CSR. Journal of Business Ethics 123 (3): 437-459. https://doi.org/10.1007/s10551-013-1847-3.

Mensching, Helge, Andrea Calabrò, Felix Eggers, and Sasha Kraus. 2016. Internationalisation of family and non-family firms: A conjoint experiment among CEOs. European Journal of International Management 10 (5): 581-604. https://doi.org/10.1504/EJIM.2016.078795.

Mesh on Demand. n.d. https://meshb.nlm.nih.gov/MeSHonDemand.

Miller, David W., and Timothy Ewest. 2013. The Present State of Workplace Spirituality: A Literature Review Considering Context, Theory, and Measurement/Assessment. Journal of Religious \& Theological Information 12 (1-2): 29-54. https://doi.org/10.1080/10477845.2013.800776.

Moher, David, Alessandro Liberati, Jennifer Tetzlaff, and Douglas G. Altman. 2010. Preferred reporting items for systematic reviews and meta-analyses: The PRISMA statement. International Journal of Surgery 8 (5): 336-341. https://doi.org/10.1016/j.ijsu.2010.02.007.

Moll, Tobias. 2020. German-language scales for spirituality at work. Journal of Management, Spirituality \& Religion 17 (3): 1-22.

Moll, Tobias. 2022. Exploring Aspects of New Work: Spirituality at work in agile organizations. Spiritual Care 11(2) (in press).

Moraru, Mădălina. 2013. Appealing to Romanian Consumers During Christmas Campaigns by Means of Religious and Traditional Aspects. Procedia - Social and Behavioral Sciences 81: 490-494. https:// doi.org/10.1016/j.sbspro.2013.06.466.

Morton, Jonathan. 2015. Spiritual practices and effective Christian leadership. Wilmore: Asbury Theological Seminary.

Mugalu, Geoffrey K. 2010. The role of senior leadership in ethical behavior of financial institutions: A case study. Minneapolis: Capella University.

Murray, Peter A., and Faiza Ali. 2017. Agency and coping strategies for ethnic and gendered minorities at work. International Journal of Human Resource Management 28 (8): 1236-1260. https://doi.org/10. 1080/09585192.2016.1166787.

Neal, Judi, and Manuel C. Vallejo. 2008. Family Firms as Incubators for Spirituality in the Workplace: Factors That Nurture Spiritual Businesses. Journal of Management, Spirituality \& Religion 5 (2): 115-159. https://doi.org/10.1080/14766080809518697.

Ngambi, Hellicy Chakosamoto. 2011. RARE total leadership: Leading with the head, heart and hands. Cape Town: Juta and Company Ltd.

Nicolae, Mariana, Irina Ion, and Elena Nicolae. 2013. The Research Agenda of Spiritual Leadership. Where Do We Stand? Review of International Comparative Management / Revista de Management Comparat International 14 (4): 551-566.

Nowrouzi, Behdin, Nancy Lightfoot, Michael Larivière, Lorraine Carter, Ellen Rukholm, Robert Schinke, and Diane Belanger-Gardner. 2015. Occupational Stress Management and Burnout Interventions in Nursing and Their Implications for Healthy Work Environments. Workplace Health \& Safety 63 (7): 308-315. https://doi.org/10.1177/2165079915576931. 
Opfinger, Matthias. 2014. Two Sides of a Medal: the Changing Relationship between Religious Diversity and Religiosity. Review of Social Economy 72 (4): 523-548. https://doi.org/10.1080/00346764.2014. 958900.

Ouarda, Dsouli, Khan Nadeem, and K. Kakabadse Nada. 2012. Spiritual capital: The co-evolution of an ethical framework based on Abrahamic religious values in the Islamic tradition. Journal of Management Development 31 (10): 1058-1076. https://doi.org/10.1108/02621711211281843.

Paal, Piret. 2018. Study Protocol: Leveraging spirituality and religion in for-profit-organizations: a mixed methods systematic review of European literature. https://www.researchgate.net/project/Leveragingspirituality-and-religion-in-for-profit-organizations-a-mixed-methods-systematic-review-of-Europ ean-literature/update/5a7433f04cde266d58883252. Accessed 15 December 2018.

Pace, Stefano. 2013. Does Religion Affect the Materialism of Consumers? An Empirical Investigation of Buddhist Ethics and the Resistance of the Self. Journal of Business Ethics 112 (1): 25-46. https://doi. org/10.1007/s10551-012-1228-3.

Paquier, Marie-Catherine. 2015. Buying monastic products, gift or purchase? Journal of Management, Spirituality and Religion 12 (3): 257-286. https://doi.org/10.1080/14766086.2015.1012738.

Parkkali, Petra, Hanna Lehtimäki, and Tojo Thatchenkery. 2015. Appreciative Intelligence®: post merger communication in a public organisation. International Journal of Human Resources Development and Management 15 (2-4): 115-127. https://doi.org/10.1504/ijhrdm.2015.071159.

Peltonen, Tuomo. 2017. Spirituality and Religion in Organizing: Beyond Secular Leadership. Berlin: Springer.

Pichler, Shaun, Enrica Ruggs, and Raymond Trau. 2017. Worker outcomes of LGBT-supportive policies: a cross-level model. Equality, Diversity and Inclusion: An International Journal 36 (1): 17-32. https:// doi.org/10.1108/EDI-07-2016-0058.

Pina e Cunha, Miguel, Stewart R. Clegg, Cláudia Costa, António Pinto Leite, Arménio Rego, Ace Volkmann Simpson, Marta Oom de Sousa, and Milton Sousa. 2017. Gemeinschaft in the midst of Gesellschaft? Love as an organizational virtue. Journal of Management, Spirituality and Religion 14 (1): 3-21. https://doi.org/10.1080/14766086.2016.1184100.

Pio, Edwina. 2010. Islamic sisters: Spirituality and ethnic entrepreneurship in Sweden. Equality, Diversity and Inclusion: An International Journal 29 (1): 113-130. https://doi.org/10.1108/026101510110192 46.

Pirkola, Heidi, Piia Rantakokko, and Marjo Suhonen. 2016. Workplace spirituality in health care: an integrated review of the literature. Journal of Nursing Management 24: 859-868. https://doi.org/10.1111/ jonm. 12398.

Pope Francis. 2015. Laudato Si' - Encyclical Letter of The Holy Father Francis on Care for Our Common Home. Vatican City. http://w2.vatican.va/content/dam/francesco/pdf/encyclicals/documents/papafrancesco_20150524_enciclica-laudato-si_en.pdf. Accessed 07 Aug 2020.

Pruzan, Peter. 2011. Spiritual-based Leadership. In: Bouckaert, L. and Zolnai, L. (Eds.) The Palgrave Handbook of Spirituality and Business. London: Palgrave Macmillan. 287-294.

Răducan, Ramona, and Radu Răducan. 2013a. Christian Religious Faith and Social Relations at Work. Procedia - Social and Behavioral Sciences 84: 411-415. https://doi.org/10.1016/j.sbspro.2013.06.576.

Răducan, Ramona, and Radu Răducan. 2013b. Landmarks of Christian and Adjustment in Romania Organizational Culture. Procedia - Social and Behavioral Sciences 84: 279-282. https://doi.org/10.1016/j. sbspro.2013.06.551.

Ratnakar, Rajesh, and Shreekumar Nair. 2012. A Review of Scientific Research on Spirituality. Business Perspectives and Research 1 (1): 1-12. https://doi.org/10.1177/2278533720120101.

Rauschnabel, Philipp A., Marc Herz, Bodo B. Schlegelmilch, and Bjoern S. Ivens. 2015. Brands and Religious labels: a spillover perspective. Journal of marketing management 31 (11-12): 1285-1309. https://doi.org/10.1080/0267257X.2015.1013489.

Rego, Arménio, Solange Souta, and Miguel Pina e Cunha. 2007. Espiritualidade nas Organizações e Comprometimento Organizacional. RAE - eletrônica 6 (2).

Rego, Arménio, and Miguel Pina e Cunha. 2008. Workplace spirituality and organizational commitment: An empirical study. Journal of Organizational Change Management 21 (1): 53-75. https://doi.org/10. $1108 / 09534810810847039$.

Roberts, Richard H. 2012. Contemplation and the Performative Absolute: Submission and identity in managerial modernity. Journal of Management, Spirituality and Religion 9 (1): 9-29. https://doi.org/10. 1080/14766086.2012.641095.

Rosenauer, Doris, Astrid C. Homan, A. L. Christiane, Horstmeier, and Sven C. Voelpel. 2016. Managing Nationality Diversity: The Interactive Effect of Leaders' Cultural Intelligence and Task Interdependence. British Journal of Management 27 (3): 628-645. https://doi.org/10.1111/1467-8551.12131. 
Rozuel, Cécile. 2014. Calling to the anima mundi: On restoring soul within organizations. Journal of Management, Spirituality and Religion 11 (2): 123-142. https://doi.org/10.1080/14766086.2013.801320.

Sabah, Senay, Alan L. Carsrud, and Akin Kocak. 2014. The impact of cultural openness, religion, and nationalism on entrepreneurial intensity: Six prototypical cases of Turkish family firms. Journal of Small Business Management 52 (2): 306-324. https://doi.org/10.1111/jsbm.12101.

Santiago, Alor J. P. 2007. Estudio exploratorio sobre el tema de la espiritualidad en el ambiente laboral. Anales de psicología 23 (1): 17-23.

Scalise, Eric T. 2007. Compathic leadership: A qualitative study to examine the cascading effects of compassion and empathy on the emotional labor of authentic leaders. Virginia Beach: Regent University.

Schardt, Connie, Martha B. Adams, Thomas Owens, Sheri Keitz, and Paul Fontelo. 2007. Utilization of the PICO framework to improve searching PubMed for clinical questions. BMC Medical Informatics and Decision Making 7 (1): 16. https://doi.org/10.1186/1472-6947-7-16.

Schlegelmilch, Bodo B., Mubbsher Munwar Khan, and Joe F. Hair. 2016. Halal endorsements: stirring controversy or gaining new customers? International Marketing Review 33 (1): 156-174. https://doi.org/ 10.1108/IMR-07-2014-0253.

Schnall, Simone, and Peter R. Cannon. 2012. The clean conscience at work: Emotions, intuitions and morality. Journal of Management, Spirituality and Religion 9 (4): 295-315. https://doi.org/10.1080/14766 086.2012.742749.

Schreurs, Bert, Hetty van Emmerik, Nele De Cuyper, Tahira Probst, Machteld van den Heuvel, and Eva Demerouti. 2014. Religiousness in times of job insecurity: Job demand or resource? Career Development International 19 (7): 755-778. https://doi.org/10.1108/CDI-08-2014-0114.

Silingiene, Violeta, and Sandrita Skeriene. 2016. Links between the spiritual intelligence of the leader and an organization's service quality: A theoretical approach. Engineering Economics 27 (1): 56-65. https://doi.org/10.5755/j01.ee.27.1.8863.

Šilingienè, Violeta, and Sandrita Škèrienè. 2015. Expression of Leaders' Spiritual Intelligence in a Context of Service Organizations: A Gender Approach. Procedia - Social and Behavioral Sciences 213: 758-763. https://doi.org/10.1016/j.sbspro.2015.11.467.

Slavik, Jan, Anna Putnova, and Andrea Cebakova. 2015. Leadership as a Tool of Strategic Management. Procedia Economics and Finance 26: 1159-1163. https://doi.org/10.1016/S2212-5671(15)00946-6.

Smith, Jonathan A., and John J. Rayment. 2007. The Global SMP fitness framework: A guide for leaders exploring the relevance of spirituality in the workplace. Management Decision 45 (2): 217-234. https://doi.org/10.1108/00251740710727250.

Stokes, Peter, Chistopher Baker, and Jessica Lichy. 2016. The Role of Embedded Individual Values, Belief and Attitudes and Spiritual Capital in Shaping Everyday Postsecular Organizational Culture. European Management Review 13 (1): 37-51. https://doi.org/10.1111/emre.12065.

Storsletten, Vivi Marie Lademoe, and Ole D. Jakobsen. 2015. Development of Leadership Theory in the Perspective of Kierkegaard's Philosophy. Journal of Business Ethics 128 (2): 337-349. https://doi. org/10.1007/s10551-014-2106-y.

Sturz, Dominick Louis, and Kara Nicole Zografos. 2014. Religious Coping and Working Past Retirement Age: A Review of the Literature. Journal of Religion, Spirituality \& Aging 26 (2/3): 231-244. https:// doi.org/10.1080/15528030.2013.855967.

Stynen, Dave, N. W. H. Jansen, and I. J. Kant. 2015. The impact of depression and diabetes mellitus on older workers' functioning. Journal of Psychosomatic Research 79 (6): 604-613.

Sullivan, Sherry E., and Yehuda Baruch. 2009. Advances in career theory and research: A critical review and agenda for future exploration. Journal of Management 35 (6): 1542-1571. https://doi.org/10. $1177 / 0149206309350082$.

Sullivan, Sherry E, Monica L. Forret, Shawn M. Carraher, and Lisa A. Mainiero,. 2009. Using the kaleidoscope career model to examine generational differences in work attitudes. Career Development International 14 (3): 284-302. https://doi.org/10.1108/13620430910966442.

Szilas, Roland Ferenc. 2014. The serving organisation and leadership for sustainable human development. World Review of Entrepreneurship, Management and Sustainable Development 10 (1): 28-39. https:// doi.org/10.1504/WREMSD.2014.058051.

Tanyeri-Erdemir, Tuğba, Zana Çitak, Theresa Weitzhofer, and Murrahem Erdem. 2013. Religion and discrimination in the workplace in Turkey: Old and contemporary challenges. International Journal of Discrimination and the Law 13 (2-3): 214-239. https://doi.org/10.1177/1358229113496701.

Tecchio, Edivandro Luiz, Cristiano José Castro de Almeida Cunha, and Fabiana Besen Santos. 2016. Spirituality in organizations? Organizações \& Sociedade [en linea] 23 (Octubre-Diciembre). http://www. redalyc.org/articulo.oa?id=400647450005. Accessed 13 November 2017.

Teeple Hopkins, Carmen. 2015. Social reproduction in France: Religious dress laws and laïcité. Women's Studies International Forum 48: 154-164. https://doi.org/10.1016/j.wsif.2014.09.002. 
Thomas, James, and Angela Harden. 2008. Methods for the thematic synthesis of qualitative research in systematic reviews. BMC Medical Research Methodology 8: 45-45. https://doi.org/10.1186/ 1471-2288-8-45.

Tracey, J. Bruce. 2014. A review of human resources management research: The past 10 years and implications for moving forward. International Journal of Contemporary Hospitality Management 26 (5): 679-705. https://doi.org/10.1108/IJCHM-02-2014-0056.

Tracey, Paul. 2012. Religion and Organization: A Critical Review of Current Trends and Future Directions. Academy of Management Annals 6 (1): 87-134. https://doi.org/10.1080/19416520.2012.660761.

Ungvári-Zrínyi, Imre. 2014. Spirituality as motivation and perspective for a socially responsible entrepreneurship. World Review of Entrepreneurship, Management and Sustainable Development 10 (1): 4-15. https://doi.org/10.1504/WREMSD.2014.058049.

United Nations. 2015. Employment, decent work for all and social protection: 2030 Agenda for Sustainable Development. https://sustainabledevelopment.un.org/topics/employment. Accessed 07 Aug 2020.

Uyar, Ali, Cemil Kuzey, Ali Haydar Güngörmüs, and Ruth Alas. 2015. Influence of theory, seniority, and religiosity on the ethical awareness of accountants. Social Responsibility Journal 11 (3): 590-604. https://doi.org/10.1108/SRJ-06-2014-0073.

Van Gordon, William, Edo Shonin, Tim Lomas, and Mark D. Griffiths. 2016. Corporate use of mindfulness and authentic spiritual transmission: Competing or compatible ideals? Mindfulness \& Compassion 1 (2): 75-83. https://doi.org/10.1016/j.mincom.2016.10.005.

Vasconcelos, Anselmo Ferreira. 2015. Older workers: some critical societal and organizational challenges. Journal of Management Development 34 (3): 352-372. https://doi.org/10.1108/JMD-02-2013-0034.

Vasconcelos, Anselmo Ferreira. 2018. Older workers as a source of wisdom capital: broadening perspectives. Revista de Gestão 25 (1): 102-118.

Volonté, Christophe. 2015. Culture and Corporate Governance: The Influence of Language and Religion in Switzerland. Management International Review 55 (1): 77-118. https://doi.org/10.1007/ s11575-014-0216-5.

Waddock, Sandra, Greta Meszoely, Steve, Waddell, and Domenico Dentoni. 2015. The complexity of wicked problems in large scale change. Journal of Organizational Change Management 28 (6): 9931012. https://doi.org/10.1108/JOCM-08-2014-0146.

Woniak, Anna. 2012. Know thy God: On Simmels philosophy, organizational spirituality and its critique. Journal of Management, Spirituality and Religion 9 (1): 31-47. https://doi.org/10.1080/14766086. 2012.641096.

Yamak, Sibel, Ali Ergur, Artun Ünsal, Selcuk Uygur, and Mustafa Özbilgin. 2015. Between a rock and a hard place: corporate elites in the context of religion and secularism in Turkey. International Journal of Human Resource Management 26 (11): 1474-1497. https://doi.org/10.1080/09585192.2014. 938678.

Zaharia, Rodica-Milena, and Laura Ramona Benchea. 2013. The Psychology Behind Religion: How is it to Work for a Muslim Company? Procedia - Social and Behavioral Sciences 84: 553-557. https://doi. org/10.1016/j.sbspro.2013.06.603.

Zsolnai, László, and Katalin Illes. 2017. Spiritually inspired creativity in business. International Journal of Social Economics 44 (2): 195-205. https://doi.org/10.1108/IJSE-06-2015-0172.

Publisher's Note Springer Nature remains neutral with regard to jurisdictional claims in published maps and institutional affiliations. 